\title{
Getting a Bad Rap? Unconscionability in Clickwrap Dispute Resolution Clauses and a Proposal for Improving the Quality of These Online Consumer "Products"
}

\author{
LUCILLE M. PONTE*
}

\section{INTRODUCTION}

The growth in online consumer spending was one of the few positive signs in an overall weak U.S. economy in 2008-2009, often outpacing brickand-mortar stores. ${ }^{1}$ The continued expansion of internet access on a variety of hand-held devices ${ }^{2}$ and increased consumer ease and confidence in online purchasing ${ }^{3}$ played important roles in this economic bright spot. In undertaking these online transactions, millions of consumers each day simply click on "I Agree" to a site's standard terms of use, often without reading or understanding the terms and conditions of their purchases. ${ }^{4}$ As online

* Professor of Law, Florida Coastal School of Law, Jacksonville, Florida. The author acknowledges and thanks Miles Weeks Mader, Florida Coastal School of Law Class of 2010 , for his research efforts on dispute resolution clauses and cases involving ecommerce sites and virtual worlds for this article.

${ }^{1}$ Press Release, comScore, Inc., Despite Weak Season, Online Spending Trends Outperform Brick-And-Mortar Across Several Key Retail Categories (Jan. 2, 2009), available at http://www.comscore.com/Press_Events/Press_Releases/2009/1/Online_ Spending_Outperforms Brick-and-Mortar.

2 Rachel Metz, EBay: Holiday Cell Phone Shopping up Threefold, AssociatED PRESS, Dec. 28, 2009, http://abcnews.go.com/technology/wirestory?id=9433458 (last visited, Nov. 29, 2010). The online auction site, eBay, reported that six million people have added eBay's applications to their iPhones with two million visits each day to eBay from mobile applications. $I d$. In 2009, eBay consumers undertook approximately $\$ 500$ million worth of transactions on their cell phones. Id. See Stephen E. Friedman, Protecting Consumers from Arbitration Provisions in Cyberspace, the Federal Arbitration Act and E-Sign Notwithstanding, 57 CATH. U. L. REv. 377, 394-409 (2008) (questioning whether online contracts, especially those on tiny cell phone screens, truly qualify as "written" agreements as intended under the Federal Arbitration Act); infra notes 4, 63-64 and accompanying text.

${ }^{3}$ See supra note 1 and accompanying text.

${ }^{4}$ Shmuel I. Becher, Asymmetric Information in Consumer Contracts: The Challenge that Is Yet to Be Met, 45 AM. Bus. L.J. 723, 726-27, 733-34, 742-43 (2008); Friedman, supra note 2, at 378; Erin Ann O'Hara, Choice of Law for Internet Transactions: The Uneasy Case for Online Consumer Protection, 153 U. PA. L. REV. 1883, 1920-21 (2005); Robert A. Hillman, Online Boilerplate: Would Mandatory Website Disclosure of E- 
consumer activities continue to grow, more consumers in the U.S. are challenging the dispute resolution clauses in these non-negotiable clickwrap agreements when conflicts arise. ${ }^{5}$ However, consumers face formidable obstacles when seeking to challenge online dispute resolution clauses because state courts largely sustain these clauses under traditional common law notions of the duty to read agreements, freedom of contract, and mutual assent between the parties. ${ }^{6}$ Furthermore, the Federal Arbitration Act (FAA)

Standard Terms Backfire?, 104 MICH. L. REV. 837, 839-40 (2006); Nancy S. Kim, Clicking and Cringing, 86 OR. L. REV. 797, 810 (2007). See Ty Tasker \& Daryn Pakcyk, Cyber-Surfing on the High Seas of Legalese: Law and Technology of Internet Agreements, 18 ALB. L.J. SCI. \& TECH. 79, 105-10 (2008) (contending that courts and lawyers fail to fully grasp the impact of website design on user reading and comprehension of clickwrap terms of use); Omri Ben-Shahar, The Myth of the "Opportunity to Read" in Contract Law 1-2, 17-19 (University of Chicago John M. Olin Program On Law \& Econ., Working Paper No. 415 2d Series, 2008); infra notes 263-65, 269 and accompanying text.

5 The term "clickwrap" agreements refers to online contracts in which the consumer or user must click on "I Agree" in order to indicate party assent to the standardized terms and conditions before the transaction or download can continue. JOSEPH M. PERILLO, Calamari AND PERILlo on ContraCts 64-65 (6th ed. 2009); Jane K. Winn \& Brian H. Bix, Diverging Perspectives on Electronic Contracting in the U.S. and EU, 54 CLEV. ST. L. REV. 175, 176-77 (2006). In a 2007 study of fifty-eight lawsuits involving clickwrap contracts, the study's author found that most initial legal challenges focused on six key aspects of these contracts of adhesion: choice of forum, choice of law, mandatory arbitration, software licensing and service terms, and liability limits. Nathan J. Davis, Note, Presumed Assent: The Judicial Acceptance of Clickwrap, 22 BERKELEY TECH. L.J. 577, 589 (2007). See infra notes 6, 18, 84-117, 126-208 and accompanying text.

${ }^{6}$ See, e.g., Guadagno v. E*Trade Bank, 592 F. Supp. 2d 1263 (C.D. Cal. 2008) (finding that an arbitration clause containing a class action waiver is not unconscionable and not a contract of adhesion as the account holder in the online investment service had clear notice of and clicked assent to a sixty day opt-out provision); In re Jamster Mktg. Litig., No. $05 \mathrm{cv} 0819 \mathrm{JM}(\mathrm{CAB}), 2008$ WL 4858506 (S.D. Cal. Nov. 10, 2008) (finding that a class action waiver contained in a reasonable and clear arbitration provision is not unconscionable under applicable Maryland, Mississippi, and Illinois laws, when the provisions compel arbitration of consumers' claims concerning deceptive business practices in free ringtone marketing scheme); A.V. v. iParadigms, 544 F. Supp. 2d 473 (E.D. Va. 2008) (finding minors had entered into valid clickwrap agreement and indicated their assent to be bound by clicking on the "I Agree" that appeared directly below online terms of use); Feldman v. Google, Inc., 513 F. Supp. 2 d 229 (E.D. Pa. 2007) (upholding mandatory arbitration in forum-selection clause); Omstead v. Dell Corp., 473 F. Supp. 2d 1018 (N.D. Cal. 2007) (finding that, in an online computer purchase, an arbitration clause with a class action waiver is not substantively unconscionable under Texas law); In re RealNetworks, Inc. Privacy Litig., No. $00 \mathrm{C}$ 1366, 2000 WL 631341 (N.D. Ill. May 8, 2000) (upholding a mandatory arbitration 
favors arbitration agreements ${ }^{7}$ while the Electronic Signatures in Global and National Commerce Act (E-SIGN) treats electronic agreements the same as written ones. ${ }^{8}$ Although E-SIGN puts forth some basic disclosure and

clause); Forrest v. Verizon Commc'ns, Inc., 805 A.2d 1007, 1011 (D.C. 2002) (upholding a state of Virginia forum selection clause that is reasonably communicated to consumers in clickwrap agreement as to font, size, appearance of terms, and opportunity to read in advance); Hubbert v. Dell Corp., 835 N.E.2d 113 (IIl. App. Ct. 2005), appeal denied, 844 N.E.2d 965 (2006) (finding a conspicuous arbitration clause with only discretionary authority to charge the losing party costs and attorneys' fees was not unconscionable in an online computer purchase); Caspi v. Microsoft Network, 732 A.2d 528 (N.J. Super. Ct. App. Div. 1999) (upholding a Washington forum selection clause where the website prompted potential subscribers to read the terms of use in advance and permitted consumers to click on "I Agree" to show mutual assent). But see DeFontes v. Dell, Inc., 984 A.2d 1061, 1072-73 (R.I. 2009) (refusing to compel arbitration because the arbitration clause stating that the return of products acts as rejection of clickwrap and shrinkwrap agreements was too confusing). See generally, William J. Condon, Jr., Electronic Assent to Online Contracts: Do Courts Consistently Enforce Clickwrap Agreements?, 16 REGENT U. L. REV. 433, 454-57 (2004) (discussing online contracts of adhesion as prima facie valid once a user clicks on "I Agree").

79 U.S.C. $\$ 2$ (2006). The FAA puts arbitration agreements on an equal footing with other contracts so that they may be struck down only on recognized legal or equitable grounds applicable to other contracts. Section 2 states that:

[a] written provision in any maritime transaction or a contract evidencing a transaction involving commerce to settle by arbitration a controversy thereafter arising out of such contract or transaction, or the refusal to perform the whole or any part thereof, or an agreement in writing to submit to arbitration an existing controversy arising out of such a contract, transaction, or refusal, shall be valid, irrevocable, and enforceable, save upon such grounds as exist at law or in equity for the revocation of any contract.

Id.

815 U.S.C. $\$ 7001$ (a) (2006). E-SIGN indicates that:

with respect to any transaction in or affecting interstate or foreign commerce-

(1) a signature, contract, or other record relating to such transaction may not be denied legal effect, validity, or enforceability solely because it is in electronic form; and

(2) a contract relating to such transaction may not be denied legal effect, validity, or enforceability solely because an electronic signature or electronic record was used in its formation.

Id. Unlike the FAA, E-SIGN provides some minimal consumer protections concerning issues of assent, including requirements for affirmative assent to the clickwrap's terms and conditions, and clear and conspicuous statements regarding access to the online 
affirmative consent requirements, neither of these laws provide any minimum standards for dispute resolution clauses in clickwrap agreements. ${ }^{9}$

While courts have generally accepted the notion that consumers may legally enter into clickwrap agreements, ${ }^{10}$ recent legal contests involving

contract in paper form. Id. $\S 7001$ (c). See Friedman, supra note 2, at 422-23. However, these provisions do not mandate any procedural or substantive components of adhesive dispute resolution clauses. 15 U.S.C. $\$ 7001$ (c) (2006). See Friedman, supra note 2, at 422-23.

${ }^{9}$ Friedman, supra note 2, at 378-79. The provisions of the proposed Uniform Computer Information Transactions Act (UCITA) concerning transactions in computer software will not be discussed in this article because only two states, Maryland and Virginia, approved the law, and efforts to seek additional state passage were suspended in August, 2003. Winn \& Bix, supra note 5, at 180; Patrick Thibodeau, Anti-UCITA Legal Measures Outnumber State Adoptions, COMPUTERWORLD.COM, June 9, 2003, http://www.computerworld.com/s/article/81884/Anti_UCITA_Legal_Measures_Outnumb er_State_Adoptions. Some experts criticized UCITA legislation for its lack of meaningful consumer protection under the proposed law. Winn \& Bix, supra note 5, at 180-81; Thibodeau, supra note 9 . Additionally, many states passed anti-UCITA legislation aimed at sustaining their state consumer protection laws. Id.

${ }^{10}$ See supra note 6 and accompanying text. It is important to note that the courts are still uncertain about whether or not browsewrap agreements, those in which contract is implied from merely viewing or visiting a website, meet the contract formation requirements for mutual assent. To date, courts have tended to be more willing to enforce browsewrap agreements against commercial parties who scraped data from other websites and financially benefitted by violating another commercial website's terms of use. See, e.g., Register.com, Inc. v. Verio, Inc., 356 F.3d 393 (2d Cir. 2004) (finding that a competitor had actual knowledge of the site's terms even though it had not clicked on the "I Agree" icon and "scraped" the WHOIS database in violation of the database's terms of use for spamming purposes); Southwest Airlines Co. v. BoardFirst, Civ. Act. No. 3: 06-CV-0891-B, 2007 WL 4823761 (N.D. Tex. Sept. 12, 2007) (finding that BoardFirst violated the terms of a browsewrap agreement through its use of Southwest Airlines' website on behalf of its customers seeking higher priority boarding passes); Cairo, Inc. v. Crossmedia Services, Inc., No. C 04-04825 JW, 2005 WL 756610 (N.D. Cal. Apr. 1, 2005) (upholding a browsewrap agreement after a competitor scraped data from sites by using "robots" showing both actual and imputed knowledge of terms). However, so far courts have rejected the enforceability of browsewrap agreements in online consumer transactions. Waters v. Earthlink Inc., 91 F. App'x. 697 (1st Cir. 2003) (determining that the ISP's customers are not bound by the arbitration clause due to a lack of notice or conspicuous links on the online agreement containing the arbitration provision); Hines v. Overstock.com, Inc., 668 F. Supp. 2d 362 (E.D.N.Y. 2009) (finding, under both New York (plaintiff's residence) and Utah (Overstock.com's location) laws, no meeting of the minds because Hines had neither actual nor constructive notice of Overstock's terms and conditions); Specht v. Netscape Commc'ns Corp., 150 F. Supp. 2d 585 (S.D.N.Y. 2001), aff'd 306 F.3d 17 (2d Cir. 2002) (finding that placement, size of text, and mild request language are insufficient to show mutual assent to the software 
online dispute resolution clauses have often focused on issues of adequate notice and substantive fairness. 11 Though contesting dispute resolution clauses is not new, ${ }^{12}$ the increasing success of these actions ${ }^{13}$ marks an important shift in judicial review of adhesive dispute resolution clauses. California and other state courts are pushing back against rubber stamping adhesive dispute resolution clauses, particularly arbitration provisions previously favored under the FAA and related precedents. ${ }^{14}$ Despite the fact that many argue that form dispute resolution clauses provide greater cost savings and certainty for consumers, ${ }^{15}$ a great number of state laws authorize state courts to strike down arbitration clauses in clickwrap agreements as unconscionable ${ }^{16}$ or as directly contravening established state public

license's clickwrap arbitration clause by consumers who download free software). See generally Christina L. Kunz, John E. Ottaviani, Elaine D. Ziff, Juliet M. Moringiello, Kathleen M. Porter \& Jennifer C. Debrow, Browse-Wrap Agreements: Validity of Implied Assent in Electronic Form Agreements, 59 BuS. L.J. 279 (2003) (addressing contract issues in browsewrap disputes, written by the Joint Working Group on Electronic Contracting Practices).

11 See infra notes 84-117, 126-208 and accompanying text.

12 The presence of an arbitration clause was typically an aspect engendering "heightened judicial scrutiny" as to the balance and faimess of contract terms in unconscionability cases. Larry A. DiMatteo \& Bruce Louis Rich, $A$ Consent Theory of Unconscionability: An Empirical Study of Law in Action, 33 FLA. ST. U. L. REV. 1067, 1079 (2006).

${ }^{13}$ Susan Randall, Judicial Attitudes Toward Arbitration and the Resurgence of Unconscionability, 52 BUFF. L. REV. 185, 194 (2004). As the use of standard arbitration clauses in a variety of commercial activities has increased, so have claims that these clauses are unconscionable. Id. In a 2002-2003 study of 235 cases with claims of unconscionability, about $68.5 \%$ involved arbitration agreements. Id. In unconscionability cases involving arbitration clauses, courts found $50.3 \%$ of them unconscionable as compared to only $25.6 \%$ of non-arbitration clause cases. See infra Parts II.B, II.C, II.D, and accompanying footnotes.

${ }^{14}$ See infra notes 84-117, 126-208 and accompanying text.

15 Davis, supra note 5, at 578-79; Florencia Marotta-Wurgler, "Unfair" Dispute Resolution Clauses: Much Ado about Nothing?, in BOILERPLATE: THE FOUNDATION OF MARKET CONTRACTS 45 (Omri Ben-Shahar ed., 2007).

16 Marotta-Wurgler, supra note 15. By comparison, when standard pre-dispute arbitration and ADR provisions are offered as a condition of offering products or services in consumer-merchant agreements in the EU, such provisions are deemed unfair and illegal. Council Directive 2000/31/EC, Directive on Electronic Commerce, 2000 O.J. (L 178) 8, available at http://eur-lex.europa.eu/LexUriServ/LexUriServ.do?uri=OJ:L:200 0:178:0001:0016:EN:PDF [hereinafter Distance Selling Directive]. See infra notes 36$37,227-29$ and accompanying text. 
policy. ${ }^{17}$ While some experts view this development as a lingering sign of judicial hostility towards arbitration, ${ }^{18}$ other commentators counter that these cases indicate state judicial willingness to counterbalance the disproportionate pro-arbitration stance of the Supreme Court and the federal judiciary, ${ }^{19}$ or the overzealous drafting of complicated and one-sided terms

17 See infra Part II.D, and accompanying footnotes.

18 Randall, supra note 13 , at 186,196 . It is important to note that some cases are striking down choice of law or forum selection clauses, not just arbitration clauses in clickwrap agreements, as unconscionable. See, e.g., Doe 1 v. AOL, 552 F.3d 1077 (9th Cir. 2009) (finding that a Virginia forum selection clause preventing class actions violates California public policy that favors consumer class actions, and is therefore unenforceable); Bragg v. Linden Research, Inc., 487 F. Supp. 2d 593 (E.D. Pa. 2007) (determining that Second Life's arbitration provision requiring a venue of San Francisco, California is unconscionable in light of the website's national presence); Comb v. PayPal, Inc., 218 F. Supp. 2d 1165, 1177 (N.D. Cal. 2002) (finding that an online payment service's choice of venue for an arbitration proceeding is unconscionable under California law based on the relative circumstances of the disputing parties).

19 See, e.g., Doctor's Assocs., Inc. v. Casarotto, 517 U.S. 681 (1996) (finding "Montana's first-page notice requirement" mandating that dispute resolution clauses be underlined, capitalized, and on the first page of contract was in conflict with the FAA); Mastrobuono v. Shearson Lehman Hutton, Inc., 514 U.S. 52 (1995) (upholding a punitive damages award in an arbitration proceeding, stating that there is no conflict between the arbitration clause and New York statutory law); Gilmer v. Interstate/Johnson Lane Corp., 500 U.S. 20 (1991) (finding that statutory age discrimination claims may be subject to mandatory arbitration); Rodriguez De Quijas v. Shearson/Am. Express, Inc., 490 U.S. 477 (1989) (supporting the utilization of arbitration to resolve matters under the Securities and Exchange Act of 1933); Shearson/Am. Express, Inc. v. McMahon, 482 U.S. 220 (1987) (upholding the use of arbitration for claims of fraud under the Securities Exchange Act of 1934 and treble damages under the Racketeer Influenced Corrupt Organizations Act); Mitsubishi Motors Corp. v. Soler Chrysler-Plymouth, Inc., 473 U.S. 614,615 (1985) (finding that a pre-dispute arbitration agreement for Sherman Antitrust Act claims does not violate public policy); Moses H. Cone Mem'l Hosp. v. Mercury Constr. Corp., 460 U.S. 1, 2 (1983) (limiting the exercise of federal courts' equitable powers when a valid arbitration agreement is in force); Scherk v. Alberto-Culver Co., 417 U.S. 506 (1974) (supporting the use of the arbitration process to resolve trademark claims under an arbitration clause in an international commercial agreement). See Jeffrey W. Stempel, Arbitration, Unconscionability, and Equilibrium: The Return of Unconscionability Analysis as a Counterweight to Arbitration Formalism, 19 ОНг ST. J. ON DISP. RESOL. 757, 840-60 (2004) (tracing the historical development and decline of the contracts doctrine of unconscionability and calling for its reemergence to counteract excessively pro-arbitration laws and precedent). In the consumer context, some critics of pre-dispute arbitration clauses in form consumer contracts contend that the judiciary has shirked its responsibility to protect consumers from one-sided agreements and permitted merchants to effectively stop consumers from pursuing their full procedural and 
of use for e-commerce clients. ${ }^{20}$ The push-back may not be signaling an overt hostility to arbitration and other forms of alternative dispute resolution (ADR) or online dispute resolution (ODR), but the failures of e-businesses to fashion ADR or ODR options that are mindful of fundamental fairness and respect for important state consumer protection concerns. ${ }^{21}$

The recent case law invalidating clickwrap dispute resolution clauses is a troubling development, not only for e-commerce businesses seeking certainty and uniformity in transacting business over the web, 22 but for the entire dispute resolution field. Scholars, educators, and practitioners have promoted the positive benefits of $\mathrm{ADR}^{23}$ and $O \mathrm{OR}^{24}$ for decades. Both $\mathrm{ADR}$ and ODR

substantive rights in disputes. Paul D. Carrington, Regulating Dispute Resolution Provisions in Adhesion Contracts, 35 HARV. J. ON LEGIS. 225, 225-28 (1998); Lucille M. Ponte, Boosting Consumer Confidence in E-Business: Recommendations for Establishing Fair and Effective Dispute Resolution Programs for B2C Online Transactions, 12 ALB. L.J. SCI. \& TECH. 441, 450-51 (2002); Jeremy Senderowicz, Consumer Arbitration and Freedom of Contract: A Proposal to Facilitate Consumers' Informed Consent to Arbitration Clauses in Form Contracts, 32 ColuM. J.L. \& SoC. ProBS. 275, 276-79 (1999).

20 Becher, supra note 4, at 743; O'Hara, supra note 4, at 1920-21; Tasker \& Pakcyk, supra note 4, at 143, 149. See Winn \& Bix, supra note 5, at 179-80. Professor Erin Ann O'Hara noted that:

[t]he difficulty with the process by which consumers enter into standard-form arrangements stems from the fact that the vendor invests substantially in the incorporation of standard terms and then presents those terms in a take-it-or-leave it fashion to the consumer who is in a hurry to complete the transaction. The consumer rarely actually reads the form and has no control over its contents. The standard forms carry with them significant efficiency advantages enjoyed by both the drafter and the consumer, but the drafter, if left completely unregulated, might have an incentive to slip in unfairly one-sided terms.

O'Hara, supra note 4, at 1920-21 (footnotes omitted).

${ }^{21}$ See Winn \& Bix, supra note 5, at 179; supra note 16 and accompanying text.

22 LuCille M. Ponte \& Thomas D. CAVENaGH, CYBERJustice: Online Dispute RESOLUTION (ODR) FOR E-COMMERCE 26-27 (Prentice Hall 2005).

23 See, e.g., ALternative DispUte RESOlution: STRATEGIES FOR LAW AND BusINESS 10, 27-28 (E. Wendy Trachte-Huber \& Stephen K. Huber eds., 1996); MARTIN A. Frey, Alternative METHODS OF Dispute Resolution 106-08, 206-07, 263-65 (Delmar Learning 2003); JACQUEline M. Nolan-HaleY, Alternative DisPUTE RESOlUtion IN A NuTShell 9-11 (West Group 2001); LuCILle M. PONTE \& ThOMAS D. Cavenagh, Alternative Dispute Resolution IN Business 31-34 (West Educational Publishing 1999).

24 See, e.g., Ethan Katsh \& JanEt RIFKIN, OnLINE Dispute Resolution: Resolving Conflicts IN CYBERSPACE 21-27 (Jossey-Bass 2001); PONTE \& CAVENAGH, 
are touted as saving time and expense, opening the lines of communication between conflicting parties, aiding in reaching more collaborative partydriven outcomes, reducing overburdened court dockets, and successfully leveraging the third-party expertise of mediators, arbitrators, and private judges that might not be found in the current judicial system. ${ }^{25}$ With all of these potential benefits to individuals and the judiciary, it seems paradoxical that consumers are challenging these ADR and ODR clauses, and that courts are willing to strike them down as unconscionable or as violations of public policy. ${ }^{26}$ These persistent challenges to dispute resolution clauses suggest that the general public does not perceive the benefits of ADR and ODR and may view ADR or ODR as legal roadblocks thwarting the fair, convenient, and inexpensive resolution of online disputes. ${ }^{27}$ The rising discord in the state courts over ADR and ODR provisions in clickwrap agreements suggests that the time has come to reassess issues of fundamental fairness and good public policy in crafting these clauses for online transactions.

To date, most e-businesses have focused primarily on exhaustive warnings about and disclosures of dispute resolution clauses. ${ }^{28}$ These detailed provisions are primarily intended to meet the requirements of contract mutual assent ${ }^{29}$ with little regard as to (1) whether consumers have any understanding what these clauses mean to them, ${ }^{30}(2)$ the relative fit

supra note 22, at 24-31; COLIN RULE, ONLINE DISPUTE RESOLUTION FOR BUSINESS: B2B, ECOMMERCE, CONSUMER, EMPLOYMENT, INSURANCE, AND OTHER COMMERCIAL CONFLICTS 61-80 (Jossey-Bass 2002).

${ }^{25}$ See supra note 23 and accompanying text.

${ }^{26}$ See supra notes 6, 18 and accompanying text; infra notes 84-117, 126-208 and accompanying text.

${ }^{27}$ See infra notes 147, 151 and accompanying text. Despite the heated debate over mandatory arbitration clauses in clickwrap agreements, a 2005 study of online software licenses found that only about six percent of these agreements required the use of arbitration. Marotta-Wurgler, supra note 15, at 50.

${ }^{28}$ See infra notes 133-41, 214-23 and accompanying text.

${ }^{29}$ See Ponte, supra note 19, at 452--57; Ben-Shahar, supra note 4, at 4; supra note 4 and accompanying text. Professor Omri Ben-Shahar indicated that mutual assent has been turned on its head because "[p]eople manifest assent, not by affirmative informed acceptance of terms, but by deciding to forego the opportunity to read." Ben-Shahar, supra note 4 , at 4.

${ }^{30}$ See Arthur Allen Leff, Unconscionability and the Crowd-Consumers and the Common Law Tradition, 31 U. PITT. L. REV. 349, 355 (1970); Richard E. Speidel, Unconscionability, Assent and Consumer Protection, 31 U. PITT. L. REV. 359, 364, 375 (1970); Ben-Shahar, supra note 4, at 2. Professor Ben-Shahar remarks that: 
between the dispute resolution method and the typical disputes in that online marketplace, ${ }^{31}$ or (3) the substantive concerns about the fundamental fairness of the selected dispute resolution processes. ${ }^{32}$ More importantly, these extensive clauses are at odds with typical web design principles that prompt consumers to scan and browse web content; not read these online materials in a detailed manner. ${ }^{33}$ In the absence of legally mandated standards for dispute resolution clauses, there has seemingly been a race to the bottom in the quality of dispute resolution clauses, ${ }^{34}$ which may explain the increasing

[c]ontract law is obsessively engaged with this problem of enhanced opportunity to read, in the name of principles of autonomy and individual power, but ironically-so I claimed in this Essay-the solutions currently offered do nothing to promote competition and robust assent. Opportunity to read fine print is sterile ammunition against the power and sophistication of contract drafters.

Id. at 34 .

31 See infra notes $146-48,158-65$ and accompanying text.

32 Ponte, supra note 19 , at $465-66$.

33 Tasker \& Pakcyk, supra note 4, at 105-06. The authors contend that courts often fail to recognize important distinctions between online clickwrap agreements and standard paper contracts based on "technical nuances" in web design. Id. at 105-06, 109. The authors assert that current presentations of terms of use fail to take into account the conventions of website design and normal user browsing habits. Id. at 105-06. The authors state that:

[w]eb site designers are taught to create a page for visitors to scan and get the gist of the content; users are not expected to read every word from top to bottom of a web page. Further, Internet developers have been catering to visitors who expect "eye-popping animations" and "mind-blowing interactivity." Web pages today can have "nifty graphics and snazzy sounds." They can incorporate "techniques used by artists in traditional animation studios." One common effect type is to have animations, images, or text changing upon the cursor rolling over a portion of a page. Such effects might draw a reader's attention away from contract terms. Imagine the difficulty of trying to concentrate on noticing or reading a contract while rapidly moving animation dances before one's eyes, or while a sound effect or a catchy tune are playing.

Indeed, a web page may be overloaded with such varied elements. In such instances, terms may be difficult to find among the clutter. Too many images on a web page can be distracting. One can easily envision a web site containing fastmoving animation that invites computer users to navigate into another topical area, thereby causing them to be distracted away from contractual provisions.

Id. (footnotes omitted). See Hillman, supra note 4, at 844.

${ }^{34}$ See infra notes $73-141$ and accompanying text. 
number of unconscionability and public policy challenges to clickwrap dispute resolution clauses. ${ }^{35}$

In the context of unconscionability, contracts scholar Professor Arthur Allen Leff argued that contracts of adhesion should not be viewed as contracts at all, but metaphorically as "products," since there is no real negotiation between the parties as found in traditional contracts. ${ }^{36}$ Professor Leff tried to reorient contracts thinkers in an era of rapid contract standardization to clearly distinguish adhesion contracts from negotiated ones. ${ }^{37} \mathrm{He}$ contended that adhesive consumer clauses should be ruled unconscionable if they "fall below a certain minimum quality." ${ }^{8}$ Borrowing from this notion in the context of dispute resolution clauses, minimum quality expectations are needed to restore a reasonable level of consumer confidence in and respect for clickwrap dispute resolution clauses. ${ }^{39}$ Like other online products or services, adhesive dispute resolution terms should have adequate consumer labeling that considers the fast-paced nature of users' online browsing habits as well as a simple rating system to help online consumers assess the basic quality of these clauses. ${ }^{40}$

This article considers major case law invalidating dispute resolution clauses in online agreements under traditional contract principles of

35 See supra note 5 and accompanying text.

${ }^{36}$ Arthur Allen Leff, Contract as Thing, 19 AM. U. L. REV. 131, 146-47 (1970); Leff, supra note 30 , at 352 n.18. See Ben-Shahar, supra note 4, at 6 . See generally Margaret Jane Radin, Online Standardization and the Integration of Text and Machine, 70 FORDHAM L. REV. 1125, 1144-46 (2002) (stating that the growing standardization of online contracts is creating a "dissolution of the distinction between text and technology" in e-commerce).

${ }^{37}$ See Leff, supra note 36 , at 131. In considering adhesion contracts as things, Professor Leff recognized that the analogy was not a perfect fit. Id. at 157 . He concluded that:

[a] consumer contract is not a thing, at least not the way cars, cows and couches are things, ... Thus the real hope of an exercise like this is necessarily more modest than any total sensory transformation. It can aspire at most temporarily to smash the semantic box in which our current thinking is locked. The next step, and the harder one, is crafting a better cabinet out of materials really available in a real world.

Id.

${ }^{38}$ Leff, supra note 30 , at $352 \mathrm{n} .18$.

39 See id.; Ben-Shahar, supra note 4, at 6; infra Part III, and accompanying footnotes.

${ }^{40}$ See infra Part IV and accompanying footnotes. 
unconscionability and public policy. ${ }^{41}$ Secondly, this article reviews the key quality issues that led state courts to strike down adhesive dispute resolution clauses. ${ }^{42}$ In light of this case law, this article proposes minimum quality standards for dispute resolution clauses in clickwrap agreements to help restore confidence in and reduce challenges to such clauses in online transactions. ${ }^{43}$ In addition, this article recommends simplified disclosure approaches better suited to typical user browsing habits, including the development of straightforward disclosure tables and a rating system to provide fast and ready identification of online merchants offering quality dispute resolution clauses in clickwrap agreements. ${ }^{44}$ This blend of minimum quality standards with simplified online disclosures will provide more accessible information to online consumers ${ }^{45}$ as well as help to motivate greater competition between online sellers over the provision of highly-rated conflict resolution methods, thereby elevating the overall quality of dispute resolution clauses in the online world. ${ }^{46}$

\section{OVERVIEW OF UNCONSCIONABILITY}

\section{A. Key Principles}

The concept of unconscionability ${ }^{47}$ dates back to Roman times ${ }^{48}$ and examines whether or not there is gross inequality, oppression, or unfair

${ }^{41}$ See infra Part II.A and accompanying footnotes; infra notes 118-25, 171-78 and accompanying text.

42 See infra notes $47-65,171-78$ and accompanying text.

${ }^{43}$ See infra Part III and accompanying footnotes.

44 See infra Part IV and accompanying footnotes. See generally Ben-Shahar, supra note 4 , at 28-33 (calling for rating and labeling regimes for all terms in standard form contracts, but suggesting that in e-commerce transactions, the absence of rating systems suggests that there may be little interest in or demand for such ratings).

45 See infra Parts III, IV and accompanying footnotes.

46 See Hillman, supra note 4, at 845-46; infra notes 289-90 and accompanying text.

47 In determining unconscionability, the famous quote is that an unconscionable agreement is "such as no man in his senses and not under delusion would make on the one hand, and as no honest and fair man would accept on the other." RESTATEMENT (SECOND) OF CONTRACTS $\S 208 \mathrm{cmt}$. b (1981) (citing Hume v. United States, 132 U.S. 406 (1889)). The notion of unconscionability is contained in both the Restatement (Second) of Contracts and the Uniform Commercial Code (U.C.C.). The relevant Restatement provision states that: 
surprise in a contractual bargain. ${ }^{49}$ Drawn from equitable principles 50 and issues of good faith and fair dealing in contracts, ${ }^{51}$ unconscionability is a question of law for the courts to decide. ${ }^{52}$ The courts, in exercising their

[i]f a contract or term thereof is unconscionable at the time the contract is made a court may refuse to enforce the contract, or may enforce the remainder of the contract without the unconscionable term, or may so limit the application of any unconscionable term as to avoid any unconscionable result.

Id. at $\S 208$.

The U.C.C. contains the following language on unconscionability:

(1) If the court as a matter of law finds the contract or any term of the contract to have been unconscionable at the time it was made, the court may refuse to enforce the contract, or it may enforce the remainder of the contract without the unconscionable term, or it may so limit the application of any unconscionable term as to avoid any unconscionable result.

(2) If it is claimed or appears to the court that the contract or any term thereof may be unconscionable, the parties shall be afforded a reasonable opportunity to present evidence as to its commercial setting, purpose, and effect to aid the court in making the determination.

U.C.C. § 2-302 (2000). See Arthur Allen Leff, Unconscionability and the Code-The Emperor's New Clause, 115 U. PA. L. REV. 485, 487-88, 558-89 (1967) (a landmark article criticizing the amorphous nature of unconscionability under the Code and the failure to clearly provide an explicit procedural-substantive dichotomy); see also DiMatteo \& Rich, supra note 12, at 1080-88 (providing an interesting overview of the scholarly debate over the meaning and application of unconscionability under the U.C.C.).

48 Charles L. Knapp, Nathan M. Crystal \& Harry G. Prince, Problems in CONTRACT LAW: CASES AND MATERIALS 584 (Wolters Kluwer 2007) (1976). In land transactions, ancient Roman law permitted nullification if one party received more than a two-to-one value in the transaction. $I d$.

49 U.C.C. $\$ 2-302$ n.l (2000); RESTATEMENT (SECOND) OF CONTRACTS $§ 208 \mathrm{cmt}$. b (1981); KNAPP ET AL., supra note 48, at 584-85; PERILLO, supra note 5, at 332, 338; Leff, supra note 47 , at 530 . In certain European nations, national laws regulate "unfair" terms in consumer contracts of adhesion with "a much lower threshold for intervention by courts and regulators than the concept of unconscionability under U.S. Contract Law, or federal and state regulation of unfair and deceptive trade practices." Winn \& Bix, supra note 5 , at 186 .

${ }^{50}$ KNAPP ET AL., supra note 48, at 584-85; PERILlo, supra note 5, at 332-33; Leff, supra note 47 , at $528-29$.

51 Restatement (SECOND) OF CONTRACTS $§ 208 \mathrm{cmt}$. a (1981); PERILlo, supra note 5, at 340. See DiMatteo \& Rich, supra note 12, at 1081.

52 U.C.C. $\$ 2-302 \mathrm{cmt} .1$ (2000); RESTATEMENT (SECOND) OF CONTRACTS $\$ 208$ cmts. b \& f (1981); Leff, supra note 47 , at 510. See Leff, supra note 30 , at 356-58 
policing efforts, are not intended to disrupt the parties' allocation of risks under the contract ${ }^{33}$-although they eventually do just that if an agreement is found unconscionable. ${ }^{54}$ Courts have long recognized unconscionability as a basis for refusing to enforce an entire agreement or the offending clauses, or limiting the application of unconscionable provisions within an agreement. ${ }^{55}$ There are two components of the concept: procedural unconscionability and substantive unconscionability. ${ }^{56}$ Some courts require a showing of both forms of unconscionability to invalidate an unconscionable clause ${ }^{57}$ while others find that a showing of either substantive or procedural unconscionability alone is sufficient. ${ }^{58}$ Unequal or superior bargaining power

(criticizing the use of courts, rather than legislation, to police unconscionable contracts); Speidel, supra note 30, at 364-65 (questioning the "expenditure of judicial energy" on unconscionability and suggesting that consumer protection laws put "more direct pressure on the professional to improve the quality of contract terms" and expecting business to justify the reasonableness of their conduct toward consumers). But see John E. Murray, Jr., Unconscionability: Unconscionability, 31 U. PITT. L. REV. 1, 40-43, 80 (1969) (arguing for respecting the value of allowing judicial determinations to develop the proper contours of U.C.C. provision on unconscionability).

53 The official comment to this U.C.C. section states that the concept of unconscionability "is one of prevention of oppression and unfair surprise and not of disturbance of allocation of risks because of superior bargaining power." U.C.C. $\S 2-302$ cmt. 1 (2000). See RESTATEMENT (SECOND) OF CONTRACTS $§ 208 \mathrm{cmt} . \mathrm{b}$ (1981).

${ }^{54}$ Murray, supra note 52, at 40-41. Professor John E. Murray asserted that if there is unfair surprise or undue hardship, "the allocation of the risks as evidenced by the writing must be disturbed." Id. at 41.

55 U.C.C. $\$ 2-302(1)$ (2000); RESTATEMENT (SECOND) OF CONTRACTS $§ 208$ (1981). See supra note 32 and accompanying text.

56 PERILLO, supra note 5, at 332, 338; Leff, supra note 47, at 487. Professor Leff first asserted this dichotomy, referring to "bargaining naughtiness as 'procedural unconscionability,' and to evils in the resulting contract as 'substantive unconscionability."' Id. See Williams v. Walker-Thomas Fumiture, 350 F.2d 445 (D.C. Cir. 1965) (a seminal case on procedural and substantive unconscionability in a consumer contract of adhesion in a rent-to-own goods transaction).

57 For example, California state courts require a showing of both procedural and substantive unconscionability, while New York state courts permit substantive unconscionability alone to serve as a basis for finding a contract unconscionable. PERILLO, supra note 5, at 282 n.14.

58 In Washington and Illinois state courts, either procedural or substantive unconscionability can provide an independent basis for an unconscionability challenge. Id. See supra note 56 and accompanying text. 
may be a part of the unconscionability analysis, but that factor by itself will not result in an agreement being found unconscionable..$^{59}$

The idea of unconscionability is also recognized throughout the EU where an emphasis is placed on consumer protection from "unfair" terms. ${ }^{60}$ Since contracts of adhesion do not allow for any individual negotiation, the EU approach recognizes market imperfections inherent in these standard form agreements and guards against the potential for harsh, one-sided terms in contracts of adhesion. ${ }^{61}$ The EU regulatory stance tries to promote good

59 U.C.C. $\$ 2-302 \mathrm{cmt} .1$ (2000); RESTATEMENT (SECOND) OF CONTRACTS $§ 208 \mathrm{cmt}$. c (1981). See PERILLO, supra note 5, at 340; Murray, supra note 52, at 41.

60 See Council Directive 93/13, Unfair Terms in Consumer Contracts, 1993 O.J. (L 95) 29-34 (EU), available at http://eur-lex.europa.eu/LexUriServ/LexUriServ.do? uri=CELEX:1993L0013:EN:HTML [hereinafter Unfair Contracts Directive]. Article 3 of the Unfair Contracts Directive states that:

1. A contractual term which has not been individually negotiated shall be regarded as unfair if, contrary to the requirement of good faith, it causes a significant imbalance in the parties' rights and obligations arising under the contract, to the detriment of the consumer.

2. A term shall always be regarded as not individually negotiated where it has been drafted in advance and the consumer has therefore not been able to influence the substance of the term, particularly in the context of a pre-formulated standard contract.

The fact that certain aspects of a term or one specific term have been individually negotiated shall not exclude the application of this Article to the rest of a contract if an overall assessment of the contract indicates that it is nevertheless a pre-formulated standard contract.

Where any seller or supplier claims that a standard term has been individually negotiated, the burden of proof in this respect shall be incumbent on him.

3. The Annex shall contain an indicative and non-exhaustive list of the terms which may be regarded as unfair.

Id. art. 3. See Council Directive 97/7, Protection of Consumers in Respect of Distance Contracts, 1997 O.J. (L 144) 19-28 (EU), available at http://eurlex.europa.eu/LexUriServ/LexUriServ.do?uri=CELEX:31997L0007:EN:HTML

[hereinafter Distance Contracts Directive] (spelling out consumer protections in online consumer-merchant transactions, including a requirement that consumers may not waive protections of their national laws or courts in online agreements); Distance Selling Directive, supra note 16 (mandating that national consumer protection laws apply equally to online consumer transactions and referencing the Distance Contracts Directive for support).

61 Winn \& Bix, supra note 5, at 183-84. See supra notes $20,30,36$ and accompanying text; infra note 138 and accompanying text. 


\section{GETTING A BAD RAP?}

faith and fair dealing in consumer transactions through detailed consumer protection laws and policies, and by mandating transparency throughout the consumer contracting process ${ }^{62}$ for both online and brick-and-mortar merchants. ${ }^{63}$ Contracts of adhesion must be written in easy to understand language, with any ambiguities interpreted in favor of the consumer. ${ }^{64}$ These types of contracts must fully disclose all contract terms before an agreement is entered into, including any terms contained in fine print or subsequently delivered to the consumer with the purchased items. ${ }^{65}$

In the EU, consumer contracts of adhesion that contain boilerplate forum selection ${ }^{66}$ and pre-dispute arbitration clauses ${ }^{67}$ are automatically viewed as

62 John R. Aguilar, Over the Rainbow: European and American Consumer Protection Policy and Remedy Conflicts on the Internet and a Possible Solution, 4 INT'L J. COMM. L. \& POL'Y 1, 17-19 (1999); Ponte, supra note 19, at 456-57; Winn \& Bix, supra note 5, at 185 . As to the EU's transparency requirements, Mr. Aguilar has indicated that:

[t] he EU requires businesses to provide a high level of product and service information, by basing many decisions upon what the consumer expected and received, and addresses "fine print" or "surprise ... terms," by requiring contractual "transparency." EU consumer policy assumes that the consumer has difficulty understanding contract terms and thus protects consumers from terms that even US lawyers recognize as a "waste[s] of time" to read or tactically placed to conceal their legal effect. Further, EU consumer policy assumes that while businesses may retain or use in-house attorneys, institute debt collection procedures or file bad credit reports, a consumer may not. Working to increase e-consumer confidence with these guarantees, EU consumer protection has become almost a fundamental right that has lessened, if not eliminated, caveat emptor.

Aguilar, supra note 62, at 20-21 (alteration in original) (emphasis and footnotes omitted).

63 Ponte, supra note 19, at 457; Winn \& Bix, supra note 5, at 185.

${ }^{64}$ Unfair Contracts Directive, supra note 60, art. 5. See Winn \& Bix, supra note 5, at $187-88$.

65 Ponte, supra note 19, at 457; Winn \& Bix, supra note 5, at 185.

66 Distance Contracts Directive, supra note 60, art. 12. Under Article 12 of that directive:

1. The consumer may not waive the rights conferred on him by the transposition of this Directive into national law.

2. Member States shall take the measures needed to ensure that the consumer does not lose the protection granted by this Directive by virtue of the choice of the law of a non-member country as the law applicable to the contract if the latter has close connection with the territory of one or more Member States.

Id. 
unfair and illegal terms under various contract and e-commerce directives. ${ }^{68}$ In the EU, the courts typically sever these unfair terms from the remaining valid terms of the consumer-merchant contractual relationship. ${ }^{69}$ Many other developed economies, such as Canada, Japan, and Australia, follow the EU approach ${ }^{70}$ rather than the U.S. approach, which emphasizes contract efficiency and places the onus on consumers to read and understand form contracts filled with legalese. 71 While the EU focuses on merchant compliance with regulatory prescriptions, the U.S. approach primarily relies on courts to make case-by-case determinations on issues of procedural and substantive unconscionability. ${ }^{72}$

\section{B. Procedural Unconscionability}

In the U.S., procedural unconscionability considers the integrity of the agreement by focusing on unfair surprise and the absence of meaningful choice as a procedural flaw in the negotiation or contract formation stage. ${ }^{73}$ Examples of procedural unconscionability often involve unsophisticated

67 The Annex to Article 3(3) of the Unfair Contracts Directive lists a number of unfair terms, including, but not limited to:

q) excluding or hindering the consumer's right to take legal action or exercise any other legal remedy, particularly by requiring the consumer to take disputes exclusively to arbitration not covered by legal provisions, unduly restricting the evidence available to him or imposing on him a burden of proof which, according to the applicable law, should lie with another party to the contract.

Unfair Contracts Directive, supra note 60, annex (1)(q). See Ponte, supra note 19, at 461-62; Tapio Puurunen, The Legislative Jurisdiction of States over Transactions in International Electronic Commerce, 18 J. MARSHALL J. COMPUTER \& INFO. L. 689, 694 $95(2000)$.

68 Ponte, supra note 19, at 461-62; Puurunen, supra note 67, at 694-95; Winn \& Bix, supra note 5, at $186-90$.

${ }^{69}$ Unfair Contracts Directive, supra note 60, art. (3)(1). See supra note 51 and accompanying text.

70 Winn \& Bix, supra note 5, at 183-84. Under certain national laws, such as in Finland, England, Wales, and Northern Ireland, pre-dispute ADR clauses are invalid in consumer contracts and the laws require that any agreement to use ADR must occur after the conflict has arisen. Ponte, supra note 19, at 461-62.

71 Ponte, supra note 19, at 456; Winn \& Bix, supra note 5, at 183-84.

72 See infra notes 73-83, 118-25, 228 and accompanying text.

73 U.C.C. $\$ 2-302 \mathrm{cmt} .1$ (2000); RESTATEMENT (SECOND) OF CONTRACTS $§ 208$ cmts. c \& d (1981); Leff, supra note 47, at 489. See PERILL, supra note 5, at 340. 
consumers who have had little opportunity to undertake a meaningful review of the contract terms, ${ }^{74}$ and therefore are surprised by a lack of clear and conspicuous contract terms. ${ }^{75}$ Other factors that may be assessed in determining procedural unconscionability include: key clauses buried in fine print, the use of extensive legalese that is difficult for the ordinary person to understand,${ }^{76}$ the failure to clearly identify how the consumer may reject the terms of an online agreement, and the existence of an arbitration clause. ${ }^{77}$ Concerns about unfair surprise can be further exacerbated by website design, including the placement and color of hyperlinks to the terms of the agreement, ${ }^{78}$ the use of indistinguishable blocks of text, ${ }^{79}$ the font size of text in the agreement, ${ }^{80}$ temporary and disappearing pop-up windows, ${ }^{81}$ and other unconventional website designs. ${ }^{82}$ Furthermore, by overloading web pages with dynamic graphics or entertaining animation, online businesses may easily divert consumer attention away from contractual terms and conditions. ${ }^{83}$

${ }^{74} \mathrm{Kunz}$ et al., supra note 10, at 295-97. See supra note 6 and accompanying text.

75 PERILlo, supra note 5, at 338-39; Kunz, et al., supra note 10, at 291-94; Tasker \& Pakcyk, supra note 4, at 90-94. See DiMatteo \& Rich, supra note 12, at 1111-12 (presenting the authors' empirical research which indicates that clear and conspicuous notice of contract terms is the key "consent-enhancing" factor in a court's determination whether or not an agreement is procedurally unconscionable). Professor Leff's assertion is that a merchant's "super-disclosure" followed by a consumer's "super-assent" might allow an otherwise unconscionable contract term to be upheld in certain instances. Leff, supra note 30, at 349-50. See supra note 6 and accompanying text; infra notes 227-28, 251-53 and accompanying text (discussing superdisclosure).

76 Restatement (SECOND) OF CONTRACTS $§ 208 \mathrm{cmt}$. d (1981); PeRILlo, supra note 5 , at 339 .

77 DeFontes v. Dell, Inc., 984 A.2d 1061, 1072-73 (R.I. 2009) (determining that agreement language that return of products constituted a rejection of clickwrap and shrinkwrap agreements was too ambiguous).

${ }^{78} \mathrm{Kunz}$ et al., supra note 10, at 305; Tasker \& Pakcyk, supra note 4, at 95-96, 10607.

79 Juliet M. Moringiello \& William L. Reynolds, Survey of the Law of Cyberspace: Electronic Contracting Cases 2007-2008, 64 Bus. LAw. 199, 214-15 (2008).

80 Tasker \& Pakcyk, supra note 4, at 132.

$81 \mathrm{Id}$. at 98-99.

82 Tasker \& Pakcyk, supra note 4, at 95-99. See Moringiello \& Reynolds, supra note 79 , at 214-15.

${ }^{83}$ Tasker \& Pakcyk, supra note 4 , at $105-07$. 
In Trujillo v. Apple Computer, Inc., ${ }^{84}$ the court dealt with a binding arbitration clause in an iPhone activation agreement that forbade class arbitrations. ${ }^{85}$ In reviewing the case facts, the court found that the consumer, who purchased the iPhone as a gift for his spouse, did not have access to a hard copy of the agreement or notice of access to online terms on the iPhone website at the time of purchase, which turned out to be an out-of-date version. ${ }^{86}$ The court determined that the Apple store had not put up any signs or placards advising consumers of the terms' availability online at time of purchase. ${ }^{87}$ Also, the court was unwilling to find that consumers should have figured out that the terms were available online. ${ }^{88}$ Subsequently, at time of phone activation, the consumer must agree to the terms of service to activate the phone. Yet, the court criticized the small window through which consumers could view the very lengthy agreement ${ }^{89}$ and castigated Apple for not providing these contract terms at the time of consumer purchase. ${ }^{90}$ The

84 Trujillo v. Apple Computer, Inc., 578 F. Supp. 2d 979 (N.D. Ill. 2008).

85 Id. at 980-81, 986. Trujillo sued AT\&T Mobility LLC (ATTM) and Apple Computer, Inc. (Apple) for misleading consumers about the life of the iPhone battery and the costs to replace it. Id. at $980-81$. The clause stated that: "wwe each agree to resolve those disputes through binding arbitration or small claims court instead of in courts of general jurisdiction' and that '[a]ny arbitration under this Agreement will take place on an individual basis; class arbitrations and class actions are not permitted." Id. at 986 (alteration in original) (citation omitted).

${ }^{86} \mathrm{Id}$. at $994-95$.

87 Id. at $989-90$.

88 Id. The court indicated that:

[o]ne might suggest that given the ubiquity of computers and access to the Internet, someone in Trujillo's position could have figured out on his own where to look online and what to look for. Putting aside the sufficiency of that proposition from a legal standpoint to establish access to ATTM's service terms, it utterly fails as a matter of evidence. Specifically, ATTM has offered no evidence that assists in bridging the gap from the theoretical availability of the obsolete version of the terms of service online (along with millions of other websites and documents) to a finding that Trujillo actually had access to it: it has offered no evidence that he was aware of the online version, that he was advised of it, or that, as a reasonable consumer, he should have known of it.

Id.

89 Id. at 986.

90 Trujillo v. Apple Computer, Inc., 578 F. Supp. 2d 979, 994-95 (N.D. Ill. 2008). 
court found the agreement to be procedurally unconscionable in light of these circumstances. 91

In Comb v. PayPal, Inc., ${ }^{92}$ the court considered an arbitration clause ${ }^{93}$ in the online terms of PayPal's electronic payment service for both consumer and business users in a class action lawsuit. ${ }^{94}$ The users claimed that PayPal froze accounts to investigate fraud claims depriving users of their funds, even funds not in dispute, in violation of state and federal laws..$^{95}$ In order to use PayPal's services, customers must agree to a very long clickwrap agreement before their application can be processed. ${ }^{96}$ Online customers are warned that by clicking on "I Agree," that they are entering into a contract and are advised to review PayPal's terms carefully before choosing to proceed. ${ }^{97}$ Under California law, a contract of adhesion is procedurally unconscionable if it is drafted by the party with superior bargaining power and provides no opportunity for other parties to negotiate its terms, allowing them only the ability to accept or reject the entire agreement. ${ }^{98}$

PayPal did not deny that a contract of adhesion was involved, but indicated that it was not procedurally unconscionable since it did not deal

91 Id. at 990 . The Trujillo court decided that since the contract was procedurally unconscionable, the court did not need to consider substantive unconscionability under Illinois law. Id.

92 Comb v. PayPal, Inc., 218 F. Supp. 2d 1165 (N.D. Cal. 2002).

93 The PayPal arbitration clause at that time stated the following:

Arbitration. Any controversy or claim arising out of or relating to this Agreement or the provision of Services shall be settled by binding arbitration in accordance with the commercial arbitration rules of the American Arbitration Association. Any such controversy or claim shall be arbitrated on an individual basis, and shall not be consolidated in any arbitration with any claim or controversy of any other party. The arbitration shall be conducted in Santa Clara County, California, and judgment on the arbitration award may be entered in any court having jurisdiction thereof. Either you or PayPal may seek any interim or preliminary relief from a court of competent jurisdiction in Santa Clara County, California necessary to protect the rights or property of you or PayPal, Inc. (or its agents, suppliers, and subcontractors) pending the completion of arbitration.

Id. at 1170 (emphasis omitted).

94 Id. at 1166.

$95 \mathrm{Id}$. at $1166-67$.

$96 \mathrm{Id}$. at 1169 . The court noted that the terms of use were "lengthy," composed "of twenty-five printed pages and eleven sections, each containing a number of subparagraphs enumerating the parties' respective obligations and duties." Id.

97 Id.

98 Comb v. PayPal, Inc., 218 F. Supp. 2d 1165, 1172-73 (N.D. Cal. 2002). 
with necessaries, such as food or clothing, ${ }^{99}$ and because users could have chosen other online electronic disbursement services if they did not wish to agree to PayPal's terms of use. ${ }^{100}$ Citing Dean Witter Reynolds, Inc. $v$. Superior Court of Alameda County, ${ }^{101}$ a case involving the validity of an arbitration clause in a stock brokerage agreement, PayPal argued "that the availability of alternative sources is enough to defeat a showing of procedural unconscionability." 102 The PayPal court rejected this argument, first distinguishing the savvy investors in Dean Witter from the unsophisticated PayPal customers whose small-dollar transactions averaged about $\$ 55.00 .{ }^{103}$ The court also noted that the investors in Dean Witter had other institutional brokerage options without arbitration provisions, but a factual dispute existed as to whether PayPal's competitors had agreements without mandatory arbitration clauses. ${ }^{104}$ In addition, the court stated that the Dean Witter court had clearly stated that "any showing of competition in the marketplace as to the desired goods and services" alone was not sufficient to overcome a claim of procedural unconscionability. ${ }^{105}$ The court concluded that PayPal's dispute resolution terms were procedurally unconscionable. 106

In another California case, Bragg v. Linden Research, Inc., ${ }^{107}$ the court relied heavily on Comb, but expanded its discussion on procedural unconscionability in a contract of adhesion in the virtual world of Second Life operated by Linden Research, Inc. (Linden). ${ }^{108}$ The conflict between the parties involved a $\$ 300$ virtual property dispute in Second Life in which Linden froze Bragg's account, preventing his access to his virtual property and funds in the account. ${ }^{109}$ The site's terms of use contained a mandatory arbitration clause under the heading "GENERAL PROVISIONS," requiring an arbitration held in San Francisco, California, applying the rules of the

${ }^{99} \mathrm{Id}$. at 1172.

${ }^{100}$ Id. at $1172-73$.

101 Dean Witter Reynolds, Inc. v. Superior Court of Alameda County, 211 Cal. App. 3d 758, 769 (Cal. Ct. App. 1989).

102 Comb, 218 F. Supp. 2d at 1172.

${ }^{103}$ Id. at $1173-74$.

104 Comb v. PayPal, Inc., 218 F. Supp. 2d 1165, 1173-74 (N.D. Cal. 2002).

105 Id. at 1173 .

106 Id.

${ }^{107}$ Bragg v. Linden Research, Inc., 487 F. Supp. 2d 593 (E.D. Pa. 2007).

${ }^{108} \mathrm{Id}$. at $603-04$.

${ }^{109}$ Id. at 597. 
International Chamber of Commerce (ICC). ${ }^{110}$ Although the party had access to the agreement in advance, the court determined that the mandatory arbitration clause in that online agreement was procedurally unconscionable, even though the consumer was an experienced attorney. 111

Similar to Comb, the court determined that a contract of adhesion is automatically procedurally unconscionable since the consumer, as the party with less bargaining power, is offered the agreement on a "take it or leave it" basis and is not permitted any meaningful opportunity for negotiation of the contract terms. ${ }^{12}$ The court noted that Bragg was an attorney, but because of the agreement's adhesive nature, Bragg was unable to apply his legal experience and negotiating skills to the terms of use. ${ }^{113}$ Consumers also did not have reasonable market alternatives to consider at that time because only Second Life offered the unique opportunity to own their virtual property. 114

The Bragg court also recognized that there was unfair surprise because the adhesive provision was buried in fine print in a long paragraph under the "benign heading "GENERAL PROVISIONS." 115 Furthermore, the clause did not contain or provide a hyperlink to information on the costs or rules of the ICC proceedings to enable consumers to evaluate the process and costs of arbitration before agreeing to the site's terms of use. ${ }^{116}$ The court found that this presentation of the terms of use further supported its finding of procedural unconscionability. 117

${ }^{110}$ Id. at $603-04$. The clause stated that:

Any dispute or claim arising out of or in connection with this Agreement or the performance, breach or termination thereof, shall be finally settled by binding arbitration in San Francisco, California under the Rules of Arbitration of the International Chamber of Commerce by three arbitrators appointed in accordance with said rules .... Notwithstanding the foregoing, either party may apply to any court of competent jurisdiction for injunctive relief or enforcement of this arbitration provision without breach of this arbitration provision.

Id. at 604 .

111 Id. at 606.

112 Id.

113 Bragg v. Linden Research, Inc., 487 F. Supp. 2d 593 (E.D. Pa. 2007).

114 Id. See generally BENJAMIN TYSON DURANSKE, VIRTUAL LAW: NAVIGATING THE LEGAL LANDSCAPE OF VIRTUAL WORLDS 86-96 (2008) (discussing the main arguments for and against the recognition of virtual property).

115 Bragg, 487 F. Supp. 2d at 606-07.

116 Id. at 607 . See infra notes 149-52, 158-65 and accompanying text.

117 Bragg, 487 F. Supp. $2 d$ at 607. 


\section{Substantive Unconscionability}

Courts examine disputed contract terms to determine if they are oppressively harsh or one-sided, and therefore substantively unconscionable. ${ }^{118}$ This situation occurs most often when there is unequal bargaining power between the contracting parties. 119 Substantive unconscionability is commonly found when contract terms involve exorbitant prices or exculpatory clauses favoring the drafter of the agreement, such as warranty disclaimers, damage limitations, or other clauses providing remedial advantages. ${ }^{120}$ Parties have successfully claimed substantive unconscionability in online agreement arbitration clauses based on the high costs of the arbitration process in relation to the amount in dispute, ${ }^{121}$ the lack of mutuality in conflict resolution options, ${ }^{122}$ the inconvenience of the venue of the mandated forum, ${ }^{123}$ the repeat player bias inherent in confidential arbitration proceedings, ${ }^{124}$ and the inability of the e-business to

118 PERILLO, supra note 5, at 332, 338; Leff, supra note 47, at 491, 497-98.

119 Perillo, supra note 5, at 338-39; Leff, supra note 47, at 552-53. See supra note 59 and accompanying text.

120 Perillo, supra note 5, at 339-40. See DiMatteo \& Rich, supra note 12, at 1107 (presenting the authors' empirical study that finds that successful unconscionability claims involved unsophisticated consumers who entered into agreements containing onesided clauses that were often excessive in price or contained exculpatory clauses favoring merchants); see also Doe v. SexSearch.com, 551 F.3d 412 (Ohio Ct. App. 2008) (determining that a user of an online adult dating service who faced criminal charges for unlawful sexual conduct with a minor failed to support claim of unconscionability under Ohio law, where the contract contained clauses limiting damage amounts, and allowed unilateral contract cancellation, and asserting unspecified clauses as substantially onesided).

121 Huff v. Liberty League Int'l, No. EDCV 08-1010-VAP (SSx), 2009 WL 1033788 , at *8 (C.D. Cal. Apr. 14, 2009) (finding unconscionable attorney fees and costs contained in online home study and sales product agreement unenforceable and severable from the remaining provisions of a valid arbitration clause); Bragg v. Linden Research, Inc., 487 F. Supp. 2d 593, 608-10 (E.D. Pa. 2007); Comb v. PayPal, Inc., 218 F. Supp. 2d 1165, 1176-77 (N.D. Cal. 2002) (finding that an online payment service's adhesive agreement that contained prohibitive arbitration fees was unconscionable under California law). Contra Hubbert v. Dell Corp., 835 N.E.2d 113, 125-26 (Ill. App. Ct. 2005), appeal denied, 844 N.E.2d 965 (Ill. 2006) (finding that a conspicuous arbitration clause giving only discretionary authority to the arbitrator to award costs and attorneys' fees was not unconscionable in an online computer purchase).

122 Bragg, 487 F. Supp. 2d at 607-08; Comb, 218 F. Supp. 2d at 1173-74.

123 See infra notes $142-48$ and accompanying text.

124 Bragg, 487 F. Supp. 2d at 610; Comb, 218 F. Supp. 2d at 1173-74. 


\section{GETTING A BAD RAP?}

show any commercial need or business reality to justify the one-sided terms. ${ }^{125}$

Both Comb and Bragg offer comprehensive reviews of substantive unconscionability to strike down their respective arbitration clauses. ${ }^{126}$ In both cases, part of the court's rationale for finding substantive unconscionabilty was based on the court's determination that the dispute resolution terms lacked mutuality. ${ }^{127}$ The courts stated that arbitration clauses can be unconscionable if the party with superior power reserves a variety of dispute resolution options for themselves while limiting the less powerful party to arbitration. ${ }^{128}$ Both courts noted that a stronger party might be able to justify the lack of mutuality by providing evidence that there is "a legitimate commercial need" for restricting dispute resolution options under the clause. ${ }^{129}$

Under Comb, the court found that the terms of use provided a range of dispute options for PayPal to exercise "at its sole discretion," including closing accounts, restricting access to accounts, withholding user funds, investigating users' financial transactions, and retaining ownership of user funds. ${ }^{130}$ PayPal also reserved the right to unilaterally modify the terms of use by posting the new or amended terms on its website without notice unless otherwise required by law. ${ }^{131}$ Users were primarily limited to using

125 Bragg, 487 F. Supp. 2d at 607-08; Comb, 218 F. Supp. 2d at 1174-75. Some scholars have indicated that merchants may be effectively constrained from using overly harsh terms in contracts of adhesion due to concerns about their goodwill and reputation amongst consumers in the marketplace. Douglas G. Baird, The Boilerplate Puzzle, in BOILERPLATE: THE Foundation OF MARKET CONTRACTS 131, 134 (Omri Ben-Shahar ed., 2007); Lucian A. Bebchuk \& Richard A. Posner, One-Sided Contracts in Competitive Consumer Markets, in BOILERPLATE: THE FOUNDATION OF MARKET CONTRACTS 3, 3 (Omri Ben-Shahar ed., 2007).

126 See infra notes 130-39 and accompanying text.

127 See infra notes 130-39 and accompanying text.

128 Comb v. PayPal, Inc., 218 F. Supp. 2d 1165, 1173 (N.D. Cal. 2002).

129 Id. at 1174.

${ }^{130} \mathrm{Id}$. at $1173-74$.

131 Id. at 1174 . So far, the issue of posting unilateral changes to agreements on company websites has produced several cases finding posting these changes without other reasonable notice does not bind customers. See, e.g., Douglas v. U. S. Dist. Court for the Cent. Dist. of Cal., 495 F.3d 1062 (9th Cir. 2007), cert. denied, 552 U.S. 1242 (2008) (finding that posting unilateral changes solely on the company's website regarding telephone services does not give reasonable notice, and users are not bound to the changed terms); Comb, 218 F. Supp. 2d at 1173 (determining that PayPal reserved the right to post unilateral changes to terms of service on its website as part of finding 
arbitration in their disputes with PayPal, but either party could seek injunctive relief from the Santa Clara County courts. ${ }^{132}$

PayPal argued that the arbitration clause did not lack mutuality because customers could seek relief in the courts for frozen amounts, while awaiting the outcome of an arbitration proceeding. ${ }^{133}$ However, in Comb, the court noted that even theoretical access to the courts can still be substantively unconscionable. ${ }^{134}$ The court countered that PayPal could freeze accounts unilaterally in its own discretion and that:

[w]hile in theory a customer may seek provisional relief in the courts, including presumably an order to unfreeze an account, the cost of doing so would be prohibitive in relation to the amounts typically in dispute. For all practical purposes, a customer may resolve disputes only after PayPal has had control of the disputed funds for an indefinite period of time. ${ }^{135}$

In striking down the arbitration clause, the court indicated that PayPal's terms were too one-sided and that PayPal failed to establish any legitimate commercial need for the limited dispute alternatives under its terms of use. ${ }^{136}$

Similarly, in Bragg, Linden reserved for itself a variety of options to resolve its conflicts with users, including the right to suspend or terminate a user's accounts, to refuse current or future service without notice or liability, and to retain a user's funds based only upon "'suspicions of fraud' or other violations of law." 137 Linden was also permitted to unilaterally amend the online agreement to change the dispute resolution terms by merely posting the changes to its website without any further notice to users. ${ }^{138}$ As in Comb, the court concluded that Linden reserved a host of self-help remedies for

PayPal's online terms to be substantively unconscionable); Briceño v. Sprint Spectrum, 911 So. 2d 176 (Fla. Dist. Ct. App. 2005) (finding that the plaintiff was bound by changes in the cell phone service agreement when he was notified on an invoice that amended terms had been posted online and he failed to cancel the revised contract).

$132 \mathrm{Comb}, 218$ F. Supp. 2d at 1173. PayPal's terms stated that "[e]ither you or PayPal may seek any interim or preliminary relief from a court of competent jurisdiction in Santa Clara County, California necessary to protect the rights or property of you or PayPal, Inc. (or its agents, suppliers, and subcontractors) pending the completion of arbitration." Id.

${ }^{133} \mathrm{Id}$. at $1174-75$.

${ }^{134}$ Comb v. PayPal, Inc., 218 F. Supp. 2d 1165, 1174-75 (N.D. Cal. 2002).

135 Id. at 1175 .

136 Id.

${ }^{137}$ Bragg v. Linden Research, Inc., 487 F. Supp. 2d 593, 608 (E.D. Pa. 2007). 138 Id. 
itself while forcing users to arbitrate their conflicts with Linden. ${ }^{139}$ In addition, the court stated that Linden's power to unilaterally revise the clause gave Linden the chance to "craft precisely the sort of asymmetrical arbitration agreement that is prohibited under California law as unconscionable." 140 The court further determined that Linden failed to provide evidence of any business realities to justify the one-sided nature of its dispute resolution clause. ${ }^{141}$

Both the Comb and Bragg courts also criticized the online businesses for limiting the venues for the arbitral forum to locations in California for customers they knew were strewn across the United States. ${ }^{142}$ In Comb, the terms of use mandated that the arbitration take place in Santa Clara County, California. ${ }^{143}$ PayPal argued that the selected venue was not unconscionable because forum selection clauses are "prima facie valid" and that such arbitral forum selection clauses are reasonable and readily upheld by courts. ${ }^{144}$ In

${ }^{139} \mathrm{Id}$.

${ }^{140}$ Id. (citing Net Global Mktg., Inc. v. Dialtone, Inc., 217 Fed. App'x. 598, 602 (Cal. 2007)). See Becher, supra note 4, at 733-34. Professor Shmuel I. Becher defines asymmetric information as existing in instances in which one party has much better access to and familiarity with information than another. Id. at 733. In the contracts context, he notes that the drafter of the form contract is far more informed and familiar with its terms and conditions while consumers are "imperfectly informed." Id. He adds that:

[t]he existence of obligational asymmetric information is a serious market failure that can undermine the efficiency of many consumer transactions. Contracts will systematically increase welfare if, and only if, contracting parties have the information necessary for an informed evaluation of all transactional aspects (including, of course, contract terms). Stated slightly differently, information inequalities belie the maxim that promisees (i.e., consumers) are the best judges of their own utility. Where imperfect information exists, the ability of parties to maximize utility via open market transactions will inevitably decrease.

Id. at 734 .

141 Bragg, 487 F. Supp. 2d at 610.

142 See Bragg, 487 F. Supp. 2d 593; Comb v. PayPal, Inc., 218 F. Supp. 2d 1165 (N.D. Cal. 2002).

${ }^{143}$ Comb, 218 F. Supp. 2d at 1176.

${ }^{144} \mathrm{Id}$. at 1176-77. In the 2005 study on End User License Agreements for software, Professor Florencia Marotta-Wurgler found that most of the studied firms did not forum shop, but reasonably opted for the location of their headquarters in their choice of forum clauses. Marotta-Wurgler, supra note 15 , at 48,63 . The study found a dearth of mandatory arbitration clauses that provide consumers with choices in their dispute resolution measures, including the opportunity for their day in court. Id. at 48,51 . In 
addition, PayPal contended that the parties were willing to litigate in California, illustrating that the venue was not "burdensome or inconvenient" for the plaintiffs. ${ }^{145}$ The court responded that the forum selection must not be unreasonable in light of the "place or manner" of the selected arbitral forum and of "the respective circumstances of the parties." 146 The court found that PayPal served millions of U.S. customers throughout the nation with the typical transaction not exceeding $\$ 55 .{ }^{147}$ Under those circumstances, the court stated that "[l]imiting venue to PayPal's backyard appears to be yet one more means by which the arbitration clause serves to shield PayPal from liability instead of providing a neutral forum in which to arbitrate disputes." 148

In Bragg, the court also considered the choice of venue of the ICC in San Francisco for the arbitration in light of the relative costs of the chosen forum and the amounts in dispute. ${ }^{149}$ The court found that the venue was unreasonable since Second Life, like PayPal, was intended to reach millions of customers across the U.S. and the typical transaction through or with Second Life involved relatively small dollar amounts. ${ }^{150} \mathrm{As}$ in Comb, the court decried Linden's choice of venue as an effort to "shield [Linden] from liability instead of providing a neutral forum in which to arbitrate disputes." 151

The Comb court further considered the prohibition of PayPal's clause that does not allow users to consolidate their claims in arbitration..$^{152}$ Looking to the California appeals decision in Szetela v. Discover Bank, ${ }^{153}$ the Comb court raised concerns that consumers would be deterred from bringing an action because only small amounts of money were in dispute, permitting a business to cheat millions of consumers without any meaningful opportunity to seek redress through collective action. ${ }^{154}$ The court indicated that the prevention of consolidated actions alone is not sufficient to invalidate an

addition, the American Arbitration Association was designated as the required third-party dispute organization in most instances. Id. at 48, 64 .

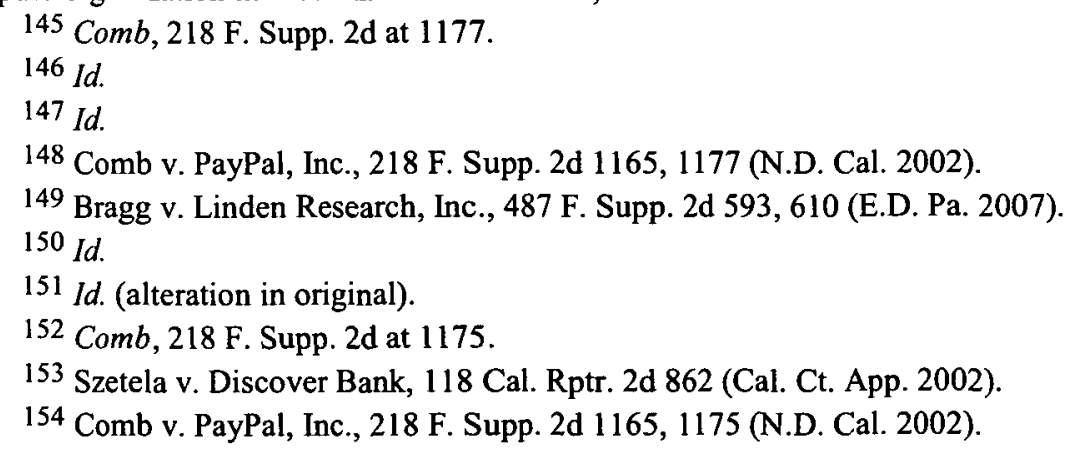


arbitration clause under California's consumer protection statutes, but when coupled with the other one-sided provisions, it permits a finding of substantive unconscionability. ${ }^{155}$ However, in later precedents, California courts have taken the view that a bar on consolidated consumer claims in an arbitration proceeding can be invalidated as unconscionable in clickwrap agreements as a violation of a fundamental state policy. ${ }^{156}$

Expanding upon Comb, the Bragg court also delved into the high costs of resolving consumer disputes before the ICC in relation to the amount of money in dispute. ${ }^{157}$ The parties disputed the relative costs of bringing an action before an ICC panel of three arbitrators - costs which would be split between the parties under the terms of use. ${ }^{158}$ The plaintiff estimated that it would cost more than $\$ 13,540$ to undertake the arbitration process, including an initiation fee of at least $\$ 10,000 .{ }^{159}$ Alternatively, Linden argued that the arbitration expenses would likely total $\$ 7,500$, with an initial fee of $\$ 3,750$. ${ }^{160}$ The court stated that even using Linden's lower estimate of upfront fees, the shared arbitration expenses were far greater than the costs of bringing the matter before a state or federal court. ${ }^{161}$ Citing Ting $v$. $A T \& T,{ }^{162}$ the court held that it is substantively unconscionable if a fee-sharing scenario in an adhesive arbitration clause imposes greater advance costs on consumers than those expected in filing traditional court actions. ${ }^{163}$ Therefore, the imbalance in the relative costs of resolving the contested funds, whether in court or in arbitration, could provide a basis for a claim of substantive unconscionability. ${ }^{164}$

155 Id. at 1176.

156 See, e.g., Oestreicher v. Alienware Corp., 502 F. Supp. 2d 1061, 1067 (N.D. Cal. 2007) (finding that a provision barring class actions in a "take it or leave it" arbitration clause cannot be enforced in online computer purchases); Brazil v. Dell Inc., No. C-0701700 RMW, 2007 WL 2255296 (N.D. Cal. Aug. 3, 2007) (determining that Texas law is not applicable to class action waiver in arbitration clause because it would violate California public policy and be substantively unconscionable as a "scheme to deliberately cheat large numbers of consumers" out of small dollar amounts).

157 Bragg v. Linden Research, Inc., 487 F. Supp. 2d 593, 608-10 (E.D. Pa. 2007).

158 Id. at 608-09.

159 Id. at 608 .

${ }^{160} \mathrm{Id}$. The court's own estimates of the costs of arbitration ranged from $\$ 17,250$ to $\$ 27,375$, depending upon the percentage of arbitrator fees. Id. at 609 .

161 Id. at $609-10$.

162 Ting v. AT\&T, 319 F.3d 1126, 1151 (9th Cir. 2003).

163 Bragg v. Linden Research, Inc., 487 F. Supp. 2d 593, 609 (E.D. Pa. 2007). 164 Id. 
The Bragg court also considered the confidential nature of the arbitral process before the ICC as supporting a claim of substantive unconscionability. ${ }^{165}$ Once again citing Ting, the court stated that the confidentiality of the method provides Linden, as the repeat player in the arbitration, with substantial advantages based upon Linden's accumulated knowledge of the arbitral procedures and outcomes so as to hone its legal position to improve its chances for success. ${ }^{166}$ However, the users are not repeat players and will not have the same experiences or advantages with the process. 167 The court recognized that confidentiality alone does not make an arbitration clause unconscionable, but when grouped with the other one-sided aspects of the provision, it resulted in a finding of substantive unconscionability. 168

\section{Public Policy Challenges to Preclusions of Class Action Arbitrations}

Dispute resolution clauses have also been found to be substantively unconscionable when the terms violate established state public policy. ${ }^{169}$ Courts may rule that these contracts are illegal bargains when contract provisions contravene state constitutional, statutory, or case law. ${ }^{170}$ Courts will refuse to enforce contract provisions in order to protect the integrity of the court system ${ }^{171}$ and to deter such future contract activities. ${ }^{172}$ In a number of dispute resolution cases, online clauses that prevent access to class actions ${ }^{173}$ or class arbitrations in consumer disputes were found to be

$165 \mathrm{Id}$. at 610 .

166 Bragg, 487 F. Supp. 2d at 610 (citing Ting).

167 Id.

168 Bragg v. Linden Research, Inc., 487 F. Supp. 2d 593, 610 (E.D. Pa. 2007).

169 RESTATEMENT (SECOND) OF CONTRACTS $§ 178(1)$ (1981); PERILlo, supra note 5, at $730-31$.

170 PERILLO, supra note 5, at 730-31. See Genelle I. Belmas \& Brian N. Larson, Clicking Away Your Speech Rights: The Enforceability of Gagwrap Licenses, 12 CoMm. L. \& POL'Y 37, 37-40, 52-53 (2007) (criticizing "gagwrap" licenses, which allow online contracts of adhesion to deprive users of free speech rights).

171 PERILLO, supra note 5, at 730.

172 Id. As one judicial decision eloquently put it, courts will not enforce illegal bargains so that "no polluted hand shall touch the pure fountains of justice." Id. at 731 (quoting Collins v. Blantern, 2 Wils. K.B. 347, 350, 95 Eng. Rep. 850, 852 (1767)).

173 See, e.g., Doe 1 v. AOL, 552 F.3d 1077 (9th Cir. 2009) (finding that a Virginia forum selection clause preventing class actions violates California's public policy 
GETTING A BAD RAP?

substantively unconscionable ${ }^{174}$ because they effectively block access to the meaningful resolution of typically small-dollar online consumer disputes. ${ }^{175}$

favoring consumer class actions, and is therefore an unenforceable online agreement); Fiser v. Dell Computer Corp., 188 P.3d 1215 (N.M. 2008) (determining that Texas law is not applicable because a ban on class action litigation or arbitration would violate New Mexico public policy and be substantively unconscionable as to the small dollar amounts for online consumer claims). Contra Adler v. Dell Inc., No. 08-CV-13170, 2008 WL 5351042 (E.D. Mich. Dec. 18, 2008) (finding an arbitration agreement containing a class action waiver provision enforceable under Texas law despite a claim that the clause might discourage consumers from seeking legal redress for small damage amounts in online computer purchases).

174 See, e.g., Oestreicher v. Alienware Corp., 502 F. Supp. 2d 1061 (N.D. Cal. 2007) (finding that a provision barring class actions in a "take it or leave it" arbitration clause cannot be enforced in online computer purchases); Brazil v. Dell Inc., No. C-07-01700 RMW, 2007 WL 2255296 (N.D. Cal. Aug. 3, 2007) (determining that Texas law cannot be used to grant a class action waiver to the arbitration clause because it would violate California public policy and be substantively unconscionable as a "scheme to deliberately cheat large numbers of consumers" out of small dollar amounts); Comb v. PayPal, Inc., 218 F. Supp. 2d 1165 (N.D. Cal. 2002) (determining that an online payment service's adhesive contract containing an arbitration clause that precludes the joinder of arbitration claims (making an individual customer's participation in arbitration more economical) is unconscionable under California law). Contra Guadagno v. E*Trade Bank, 592 F. Supp. 2d 1263, 1271 (C.D. Cal. 2008) (finding that an arbitration clause containing a class action waiver is not unconscionable and not a contract of adhesion because the terms were "clear and reasonably conspicuous" and the consumer agreed to the terms by clicking the acknowledgement icon); Adler, 2008 WL 5351042 (determining an arbitration agreement containing a class action waiver provision is enforceable under Texas law despite a claim that the clause might discourage consumers from seeking legal redress for small damage amounts in online computer purchases); In re Jamster Mktg. Litig., No. 05cv0819 JM(CAB), 2008 WL 4858506 (S.D. Cal. Nov. 10, 2008) (finding that a class action waiver contained in a reasonable and clear arbitration provision is not unconscionable under applicable Maryland, Mississippi, or Illinois laws, and compelling arbitration of consumers' claims concerning deceptive business practices in a free ringtone marketing scheme); Omstead v. Dell Corp., 473 F. Supp. 2d 1018 (N.D. Cal. 2007) (finding that, in online computer purchases, an arbitration clause with a class action waiver is not substantively unconscionable under Texas law).

175 Typically, e-commerce involves small dollar amount purchases and consumers located in different states that have divergent consumer protection laws. See supra notes $146-48,158-65$ and accompanying text. The vast majority of online consumer disputes involve relatively small dollar amounts, typically $\$ 300-\$ 3,000$. PONTE \& CAVENAGH, supra note 22 , at 12 . These comparatively small dollar amounts, coupled with time and travel expenses, make face-to-face judicial or ADR methods unrealistic for many online consumers. Id. 
If such clauses contravene an established state law or policy, the clauses may be found substantively unconscionable, and therefore unenforceable. ${ }^{176}$

After Comb, the California courts have applied the three-prong analysis from Discover Bank v. Superior Court of Los Angeles. ${ }^{177}$ The court in Discover Bank held that an arbitration clause precluding collective action in credit card holder disputes was a violation of public policy. ${ }^{178}$ Applying the three-prong test, the Discover Bank court found that a class action waiver violates public policy, and is therefore unconscionable if: (1) the arbitration clause is contained in a contract of adhesion, (2) the typical arbitral dispute involves small dollar amounts, and (3) the party with superior bargaining power sought to "deliberately cheat large numbers of customers out of individually small sums of money."179

Subsequently, the court in Oestreicher $v$. Alienware Corp. ${ }^{180}$ held a mandatory arbitration clause ${ }^{181}$ in a clickwrap agreement for the purchase of a laptop computer was a violation of public policy and thereby unconscionable. ${ }^{182}$ Under the terms of use, the governing law was that of the

176 See infra notes 179-208 and accompanying text.

177 Discover Bank v. Sup. Ct. of Los Angeles, 36 Cal. 4th 148, 152 (Cal. 2005).

178 Id. at 155. See Klussman v. Cross Country Bank, 134 Cal. App. 4th 1283 (Cal. Ct. App. 2005) (finding that a waiver of the right to bring classwide arbitration in consumer cardholder agreements is unconscionable under California law and is not severable from the arbitration clause).

179 Discover Bank, 36 Cal. 4th at 162-63.

180 Oestreicher v. Alienware Corp., 502 F. Supp. 2d 1061 (N.D. Cal. 2007).

$181 \mathrm{Id}$. at 1063 . The Alienware arbitration clause indicated that any dispute relating to a computer purchase:

SHALL BE RESOLVED EXCLUSIVELY AND FINALLY BY BINDING ARBITRATION ADMINISTERED BY THE NATIONAL ARBITRATION FORUM .... YOU UNDERSTAND THAT IN THE ABSENCE OF THIS PROVISION, YOU WOULD HAVE HAD A RIGHT TO LITIGATE DISPUTES THROUGH A COURT, INCLUDING THE RIGHT TO LITIGATE CLAIMS ON A CLASS-WIDE OR CLASS-ACTION BASIS, AND THAT YOU HAVE EXPRESSLY AND KNOWINGLY WAIVED THOSE RIGHTS AND AGREED TO RESOLVE ANY DISPUTES THROUGH BINDING ARBITRATION IN ACCORDANCE WITH THIS SECTION.

Id.

182 Id. at 1071-72. See Brazil v. Dell Inc., No. C-07-01700 RMW, 2007 WL 2255296 (N.D. Cal. Aug. 3, 2007) (determining that Texas law cannot grant a class action waiver to the arbitration clause because it would violate California public policy and be substantively unconscionable as a "scheme to deliberately cheat large numbers of consumers" out of small dollar amounts). 
state of Florida, which was the principal place of business for Alienware, the laptop vendor. ${ }^{183}$ The parties disputed whether Oestreicher ever agreed to the clickwrap agreement terms of use because online consumers could order defendant's notebook computers without actually having to access and read the agreement's terms. ${ }^{184}$ Oestreicher brought a variety of claims against Alienware contending that the company knew about the defects in the laptops it sold. ${ }^{185}$ In response to the lawsuit, Alienware motioned to compel arbitration pursuant to the arbitration clause and in accordance with the Florida choice of law clause. ${ }^{186}$

Applying California law and the Discover Bank analysis, ${ }^{187}$ the court found that Oestreicher had minimally made out his claim of procedural unconscionability since the clickwrap agreement was presented on a take-itor-leave-it basis without a chance for the consumer to negotiate the terms. ${ }^{188}$ However, the disputed amount was above $\$ 1,000$, which may mean the lawsuit did not involve a small dollar amount. ${ }^{189}$ The court determined that the purchase price was "not insignificant, but also not substantial," but ultimately found that the second factor as to small dollar amounts was adequately met. ${ }^{190}$ Lastly, the court determined that the plaintiff had sufficiently pled that Alienware knew and deliberately concealed the laptop defects and failed to properly remedy the defects before selling the computers. ${ }^{191}$ The court decided that Oestreicher had satisfied this third factor, which allowed the court to conclude that the preclusion of class action arbitration in this instance violated public policy and showed "a high degree of substantive unconscionability."192 Therefore, the court determined that the preclusion of class actions under the adhesive arbitration clause was an unconscionable contract term and would not be enforced. ${ }^{193}$

183 Oestreicher, 502 F. Supp. 2d at 1063-64.

184 Id. at 1063.

$185 \mathrm{Id}$. at 1064 . The plaintiff purchased the notebook laptop for $\$ 4,149$ via Alienware's website and asserted that the laptop overheated, shut down, and was no longer operating about six months later. Id.

186 Oestreicher v. Alienware Corp., 502 F. Supp. 2d 1061, 1064 (N.D. Cal. 2007).

187 Discover Bank v. Sup. Ct. of Los Angeles, 36 Cal. 4th 148, 162-63 (Cal. 2005).

188 Oestreicher, 502 F. Supp. 2d at 1067, 1070.

${ }^{189}$ Id. at $1067-68$.

190 Id. at 1068 .

${ }^{191}$ Id.

192 Oestreicher v. Alienware Corp., 502 F. Supp. 2d 1061, 1070 (N.D. Cal. 2007).

193 Id. at 1071-72. The court found that the arbitration clause as a whole was procedurally unconscionable, but not substantively unconscionable. Id. at 1070-71. 
In Fiser v. Dell Computer Corp. ${ }^{194}$ the New Mexico court faced the issue of public policy in preventing online consumers from consolidating their claims in an arbitral proceeding as well. The plaintiff bought a computer from Dell's website. ${ }^{195} \mathrm{He}$ later tried to bring a class action suit against Dell claiming that the company had systematically misrepresented the size of their computer memory in violation of New Mexico statutes and common law principles. ${ }^{196}$ The estimated loss due to the claimed misrepresentation, about ten to twenty dollars per computer, played a central role in the court's review of the online purchase agreement. ${ }^{197}$ The online agreement provided for the application of Texas law and contained an arbitration clause that prevented class actions in the arbitral forum. ${ }^{198}$

The court recognized a well-established New Mexico public policy outlined in its statutes that favored collective consumer action. ${ }^{199}$ Unlike the emphasis on small dollar amounts in the Discover Bank analysis, ${ }^{200}$ New Mexico public policy promotes the vindication of consumer rights, regardless of dollar amount. ${ }^{201}$ The New Mexico Uniform Arbitration Act explicitly states that arbitration clauses that ban consumer participation in class action arbitration proceedings are unenforceable and voidable. ${ }^{202}$ In addition, New Mexico also values the class action as a key method for the "vindication of the rights of groups of people who individually would be without effective strength to bring their opponents into court at all." ${ }^{203}$ In turn, the court

Ultimately, Alienware indicated that striking the prohibition against collective action under the arbitration clause would obviate its goal to use arbitration to handle its disputes. Id. at 1071-72. Therefore, the court declared the entire arbitration clause unenforceable. Id. at 1072.

194 Fiser v. Dell Computer Corp., 188 P.3d 1215 (N.M. 2008).

195 Id. at 1217.

196 Id. The plaintiff claimed violations of the New Mexico Unfair Practices Act (UPA), the New Mexico False Advertising Act, and the New Mexico U.C.C., as well as common law claims of breach of contract and warranty, misrepresentation, violations of good faith and fair dealing, bad faith, and unjust enrichment. Id.

197 Id.

198 Id. at $1217-18$.

199 Id. at $1218-19$.

200 See supra notes $179-80$ and accompanying text.

201 Fiser v. Dell Computer Corp., 188 P.3d 1215, 1218 (N.M. 2008).

202 Id. at 1219.

203 Id. (quoting Romero v. Phillip Morris, Inc., 109 P.3d 768 (N.M. Ct. App. 2005)). Reviewing U.S. Supreme Court precedent, the Fiser court recognized the importance of class actions in helping to aggregate claims in a way that would permit consumers facing 
rejected the Texas choice of law clause because Texas law would uphold the ban on class action in arbitration (as well as in litigation) which contradicted existing New Mexico public policy. ${ }^{204}$ However, a number of courts, some even in California, have found that a bar on collective actions in arbitration clauses in certain circumstances is not always against public policy and thereby unconscionable. ${ }^{205}$ This lack of consistency in court rulings as to public policy and preclusion of consolidated arbitration actions leads both users and online businesses to be confused about the validity of such clauses. ${ }^{206}$

small-dollar disputes to gain access to legal representation and preserve party resources. Id. The court stated that the Supreme Court has indicated that:

[t] $\mathrm{the}$ policy at the very core of the class action mechanism is to overcome the problem that small recoveries do not provide the incentive for any individual to bring a solo action prosecuting his or her rights. A class action solves this problem by aggregating the relatively paltry potential recoveries into something worth someone's (usually an attorney's) labor.

Id. (quoting Amchem Prods., Inc. v. Windsor, 521 U.S. 591 (1997)). Also, the Supreme Court has recognized that: "[w]here it is not economically feasible to obtain relief within the traditional framework of a multiplicity of small individual suits for damages, aggrieved persons may be without any effective redress unless they may employ the class-action device." Id. (quoting Deposit Guar. Nat'l Bank, Jackson, Miss. v. Roper, 445 U.S. $326(1980)$ ).

204 Id.

205 See, e.g., Guadagno v. E*Trade Bank, 592 F. Supp. 2d 1263 (C.D. Cal. 2008)

(finding that an arbitration clause containing a class action waiver is not unconscionable and not a contract of adhesion because the account holder in the online investment service had sixty days to opt-out); Adler v. Dell Inc., No. 08-CV-13170, 2008 WL 5351042 (E.D. Mich. Dec. 18, 2008) (determining that an arbitration agreement containing a class action waiver provision was enforceable under Texas law despite a claim that the clause might discourage consumers from seeking legal redress for small damage amounts in online computer purchases); In re Jamster Mktg. Litig., No. $05 \mathrm{cv} 0819 \mathrm{JM}(\mathrm{CAB}), 2008 \mathrm{WL} 4858506$ (S.D. Cal. Nov. 10, 2008) (finding that a class action waiver contained in a reasonable and clear arbitration provision is not unconscionable under applicable Maryland, Mississippi, or Illinois laws, and compelling arbitration of consumers' claims concerning deceptive business practices in the free ringtone marketing scheme); Omstead v. Dell Corp., 473 F. Supp. 2d 1018 (N.D. Cal. 2007) (finding that, in online computer purchases, an arbitration clause with a class action waiver is not substantively unconscionable under Texas law).

206 See infra note 225 and accompanying text. 


\section{ESTABLISHING MINIMUM QUALITY STANDARDS FOR CLICKWRAP DispuTE RESOLUTION ClAUSES}

In response to unconscionability challenges, some online businesses have moved to revise their clickwrap dispute resolution clauses to offer more userfriendly options, while others have continued to retain questionable clauses that have been invalidated in prior court decisions. ${ }^{207}$ For example, stung by their legal challenges, both PayPal and Second Life 208 revised their arbitration clauses to nearly identical terms. In response to the court challenge, PayPal made efforts to make multiple cost-effective options available to its users, allowing them to choose which one they would use in resolving their online disputes. ${ }^{209}$ Under its revised terms, PayPal permits users to litigate their claims in either Santa Clara County, California, or Omaha, Nebraska, applying the laws of California, ${ }^{210}$ or to arbitrate damage claims under $\$ 10,000.211$ For disputes involving small-dollar damage amounts, users may select "a cost effective manner through binding nonappearance-based arbitration" to resolve their claims. ${ }^{212}$ The parties must mutually agree upon the ADR provider, ${ }^{213}$ but the arbitration process is conducted solely at the user's option:

a) the arbitration shall be conducted by telephone, online and/or be solely based on written submissions, the specific manner shall be chosen by the party initiating the arbitration; b) the arbitration shall not involve any

207 See id.

208 Second Life, Terms of Service, $\S 12$, http://secondlife.com/corporate/tos.php (last visited Aug. 31, 2010) [hereinafter SL Terms].

209 PayPal User Agreement, §14.2, https://cms.paypal.com/us/cgibin/?\&cmd=_render-content\&content_ID=ua/UserAgreement_full\&locale.x=en_US\#14 (last visited Jan. 31, 2010) [hereinafter PayPal Terms]. The clause states that:

[f]or any claim (excluding claims for injunctive or other equitable relief) where the total amount of the award sought is less than $\$ 10,000.00$ USD, the party requesting relief may elect to resolve the dispute in a cost effective manner through binding non-appearance-based arbitration. If a party elects arbitration, that party will initiate such arbitration through an established alternative dispute resolution (ADR) provider mutually agreed upon by the parties.

Id.
210 Id. $\S 14.3$.
211 Id. $\S 14.2$.
212 Id.
${ }^{213}$ Id. 
personal appearance by the parties or witnesses unless otherwise mutually agreed by the parties; and c) any judgment on the award rendered by the arbitrator may be entered in any court of competent jurisdiction.

Furthermore, the online payment service no longer contains clauses precluding class actions or consolidated actions. ${ }^{215}$ PayPal also suggests that users contact its customer service department first, either online or by telephone, to help address user issues and to offer users "a neutral and cost effective means of resolving the dispute quickly."216

In changing its terms of use, Second Life largely tracks the language of PayPal's dispute resolution clauses. ${ }^{217}$ The revised terms provide choice and cost-sensitive options ${ }^{218}$ to its users who are no longer limited to mandatory ICC arbitration in San Francisco. As with PayPal, users are allowed to choose to litigate disputes in San Francisco, California or to arbitrate damage claims under $\$ 10,000 .^{219}$ Like PayPal, for disputes involving small dollar damage amounts, users may also elect to use "binding non-appearance-based arbitration" to handle their disputes. ${ }^{220}$ The user and Second Life must mutually agree upon the ADR provider; this change reflects the same basic characteristic as the PayPal arbitral process. ${ }^{221}$

In Paypal and Bragg, unconscionability challenges clearly had an impact on the dispute resolution terms in the clickwrap agreements that impacted consumers throughout the U.S. But legal challenges to bars to collective action under arbitration clauses have yielded a more spotty record. While PayPal dropped its ban on collective action in its arbitration clause, successful challenges in California and New Mexico to the clickwrap agreements of Dell and Alienware did not cause Dell and Alienware to make any meaningful change in their preclusion language. ${ }^{222}$ Both companies have

214 Id.

215 Paypal Terms, supra note $211, \S 14.2$.

216 Id. $\S 14.1$.

217 SL Terms, supra note $210, \S 12$.

218 Id. In its dispute resolution preamble, Linden declares that "[i]f $\mathrm{f}$ dispute arises between you and Linden Lab... [o]ur goal is to provide you with a neutral and costeffective means of resolving the dispute quickly." Id. $\S 12.1$.

${ }^{219}$ Id. $\S \S 12.1-12.2$.

220 Id. $\$ 12.1$.

221 Id. This clause is identical to PayPal's provisions.

222 See infra note 225 and accompanying text. 
retained arbitration clauses in their clickwrap agreements that bar collective action in online user disputes. ${ }^{223}$

The disagreement between courts on issues of unconscionability and public policy makes it difficult for online businesses to uniformly and efficiently process online consumer transactions across state borders. More importantly, this discord sets up a two-tier system amongst online users in different states who will continue to receive different levels of protection, often regarding the exact same dispute resolution clauses in clickwrap agreements. For example, online customers in California will typically retain some level of choice between litigation and arbitration, elect arbitration methods that take into account the dollar amounts of their disputes and the fairness of the location, and be permitted to consider collective action in arbitral proceedings in small dollar amount conflicts. Yet, Texas users who agree to the same adhesive clauses cannot count on any of these protections which in many cases results in no meaningful opportunity to vindicate their rights in small-dollar disputes. While businesses may prefer these favorable terms, users will be confused about their legal options and rights. 224 In the past, various ADR organizations put together guidelines for fair and effective dispute resolution procedures and providers, with an emphasis on more detailed disclosures to consumers; these proposed standards have not been widely embraced. ${ }^{225}$ In the context of unconscionability, Professor Leff

${ }^{223}$ Despite its involvement in numerous legal challenges, Dell retains a Terms of Sale provision containing an arbitration clause that prohibits collective action in arbitration. The clause states:

In any dispute, NEITHER CUSTOMER NOR DELL SHALL BE ENTITLED TO JOIN OR CONSOLIDATE CLAIMS BY OR AGAINST OTHER CUSTOMERS, OR ARBITRATE ANY CLAIM AS A REPRESENTATIVE OR CLASS ACTION OR IN A PRIVATE ATTORNEY GENERAL CAPACITY. The individual (non-class) nature of this dispute provision goes to the essence of the parties' dispute resolution agreement, and if found unenforceable, the entire arbitration and dispute resolution provision shall not be enforced.

Dell, U.S. Consumer Terms of Sale, $\S 12$, http://www.dell.com (follow "Terms of Sale" hyperlink) (last visited Jan. 31, 2010). Alienware's Terms and Conditions provision also still precludes class action arbitration actions. Alienware, Alienware: Terms \& Conditions, $\S 11$, http://www.alienware.com/purchase/customer-terms.aspx (last visited Jan. 31, 2010).

224 Ponte, supra note 19, at 463-64.

225 See, e.g., National Arbitration Forum, Arbitration Bill of Rights with Commentary (2007), http://www.adrforum.com/users/naf/resources/ArbitrationBillOfRights3.pdf (last visited Jan. 31, 2010); American Arbitration Association, Consumer Due Process Protocol: Statement of Principles of the National Consumer Disputes Advisory 
opined that standard form contracts for consumers were not true contracts, but were more like "products" that should be required to meet basic standards of quality. ${ }^{226}$ Professor Leff was highly critical of efforts to police unconscionable consumer contracts through the courts, believing that a caseby-case review leads to little or no change in the marketplace. ${ }^{227} \mathrm{He}$

Committee, Consumer Due Process Protocol, (April 10, 1998), http://www.adr.org/sp.asp?id=22019 (last visited Jan. 31, 2010); American Bar Association Task Force on Ecommerce and ADR, Recommended Best Practices for Online Dispute Resolution Service Providers (Aug. 2002), http://www.abanet.org/dispute/documents/BestPracticesFinal102802.pdf (last visited Jan. $31,2010)$. See supra note 73 and accompanying text. See generally Ponte, supra note 19 (discussing and proposing minimum standards and online website disclosures for ODR). Also, Professor Hillman further warns that mandating disclosure will not incentivize consumers to compare contract terms and may result in "suspect terms" being adjudged as enforceable. Hillman, supra note 4, at 839.

226 Leff, supra note 36 , at 147 ; Leff, supra note 30 , at $352 \mathrm{n} .18$. See Radin, supra note 36, at 1139-40. Professor Margaret Jane Radin indicated that, in the online world "[t]he contract is merging into the product; the text is merging into the functionality." Id. at 1140 .

$$
{ }^{227} \text { Leff, supra note } 30 \text {, at 356-58. He stated that: }
$$

[o]ne cannot think of a more expensive and frustrating course than to seek to regulate goods or "contract" quality through repeated lawsuits against inventive "wrongdoers."... Wouldn't it be better, finally, to face the political problems and pass a statute that deals with . . . a wide panoply of [crooked] marketing devices, and so on, and maybe even gross overpricing ... and tuck in, along with private causes of action for the victims, an administrative enforcement arm to police these repetitive nasty practices (and perhaps get compensation for the whole class of bilked consumers theretofore identifiably bilked)? Isn't there some economy of scale in that approach?

... The key factor I suppose, is that in dealing with mass vices in mass contracts, administration by way of the litigation bureaucracy is likely to have only trivial impact, for good or evil. One does not cure any serious breakdown in a theoretically competitive market system by case-to-case sniping.

Id. (footnotes omitted). See infra note 229 and accompanying text. Similarly, law and economics scholars have argued that terms that may appear onerous on their face are often ignored in practice and contend that "[i]n some circumstances, a strategy of discretionary protection [by businesses] is superior to a strategy of judicial discretion." Bebchuk \& Posner, supra note 125, at 7. But see Davis, supra note 5, at 598 (contending that courts have been quite capable of adjudicating clickwrap disputes in a manner that protects consumers from harsh terms while retaining the economic benefits of such agreements). 
predicted that litigation might yield more explicit legal disclosures, but no meaningful improvement in consumer understanding or contract fairness. ${ }^{228}$

Analogizing to product safety, Professor Leff noted that government regulation to quality needed to be limited "to important characteristics of the product." 229 By looking at adhesion contracts as more similar to goods than to traditional contracts, Professor Leff recommended that adhesion contracts should be of "fair average quality ... within the trade," 230 similar to the earlier common law requirement for goods, which was subsequently codified in the U.C.C. ${ }^{231}$ Reflecting Professor Leff's perspective, it is important to establish key minimum standards for clickwrap dispute resolution clauses

228 Leff, supra note 30, at 357-58. See Hillman, supra note 4, at 855; Speidel, supra note 30 , at 364 (emphasizing that detailed disclosures in contracts of adhesion are unlikely to result in more informed consumer choice); Ben-Shahar, supra note 4, at 3-5. Professor Robert A. Hillman adds that legislative bodies tend to focus on disclosure as the cure for unfair terms without realizing that this approach "may [put] consumers in a worse position than the status quo and even forestall other attempts at reform." Hillman, supra note 4 , at 855 . See supra note 73 and accompanying text. In addition, Professor Michelle Boardman indicates that the ambiguous boilerplate language used today is fashioned not to befuddle or defraud consumers, but to speak to judges who will apply existing legal precedent to similar clauses with similar language. Michelle E. Boardman, Contra Proferentem: The Allure of Ambiguous Boilerplate, in BOILERPLATE: THE FOUNDATION OF MARKET CONTRACTS 176, 176-78 (Omri Ben-Shahar ed., 2007). She states that:

[t]here is a hidden allure to ambiguous boilerplate, but the trick lies in the courts, not the consumer. The trick is a private conversation between drafters and courts; excused from the table is the consumer, who could have no fair duty to understand and so has no duty to read. With the consumer out of the room, edits and additions to boilerplate are targeted to courts alone. The new language does not need to make sense to a layman. It does not even need to make sense standing alone; a judge will read the language in the context of precedent, with the aid of briefing.

Id. at 176 (emphasis omitted). Boardman notes that insurance policies are a good example of this legal conversation that excludes customers and focuses on addressing anticipated judicial review. Id. at 181 . She warned that courts need to recognize that businesses are by-passing consumers in drafting complex boilerplate language and should "be wary of creating perverse incentives to retain the very clauses that they seek to change" in protecting consumers from onerous boilerplate provisions. Id. at 185.

${ }^{229}$ Leff, supra note 30, at 353 n.19. See Leff, supra note 36, at 149-50.

${ }^{230}$ Leff, supra note 36 , at 151 . See Leff, supra note 30 , at $352 \mathrm{n} .18$; Ben-Shahar, supra note 4 , at 6.

${ }^{231}$ Leff, supra note 30 , at 356-58. This common law approach was later codified under the U.C.C. as the concept of the implied warranty of merchantability. U.C.C. $\S 2-$ 314 (2001). 
that are drawn from case law determinations in order to avoid future judicial findings of procedural and substantive unconscionability. ${ }^{232}$ These minimum standards must be augmented by simplified online disclosures that better reflect the existing nature of website browsing as opposed to typical real world review of paper contracts. ${ }^{233}$ An additional improvement would be to use marketplace ratings or rankings of quality compliance in online merchants' terms of use. These rankings, maintained by a consumer trustmark organization, will help to improve marketplace competition and improve the quality of clickwrap dispute resolution clauses. ${ }^{234}$

In regards to procedural unconscionability, clickwrap agreements already are often viewed as procedurally unconscionable because they are presented on a take-it-or-leave-it basis. To ameliorate concerns about a clickwrap agreement, the minimum standards must emphasize advance notice and clarity of the dispute resolution terms in the contract formation stage. ${ }^{235}$ Clear and conspicuous notice of the dispute resolution terms must be provided prior to when users click on whether or not they agree to the terms of use. ${ }^{236}$ The minimum standards should also mandate that dispute resolution terms should be written in plain English, and not be buried in fine print or hidden in a mound of legalese. ${ }^{237}$

To avoid claims of substantive unconscionability, clickwrap dispute resolution clauses should emphasize mutuality, choice, cost-effectiveness, and transparency. To address mutuality, online merchants should not reserve a host of dispute resolution options for themselves while mandating the users' process options. ${ }^{238}$ The terms of use should provide either comparable options between the users and the merchant or opportunities to participate in selecting the dispute resolution methods and qualified neutral decisionmaker(s) who will help process their claims. ${ }^{239}$

It also makes good business sense to include an escalation clause that recommends that consumers first seek to resolve the matter with the merchant's customer service department, as found in the revised PayPal terms of use, before moving on to more formal dispute resolution

\footnotetext{
232 See supra notes 84-117, 126-70 and accompanying text.

233 See supra notes $33,78-83$ and accompanying text.

234 See infra notes $282-87$ and accompanying text.

235 See supra notes 74-77 and accompanying text.

236 See supra note 75 and accompanying text.

237 See supra notes 76, 79-80 and accompanying text.

238 See supra notes $126-41$ and accompanying text.

${ }^{239}$ See supra notes 211-23 and accompanying text.
} 
processes. ${ }^{240}$ The online merchant should provide users with choices in their dispute resolution methods that reflects the merchant's own dispute resolution options under the clickwrap terms of use. ${ }^{241}$ If the merchant requires users to litigate or arbitrate, then the merchant should similarly limit its dispute resolution options. ${ }^{242}$ Yet, if the online business wishes to maintain flexibility in its own dispute resolution methods, then it should identify the user's options in the clickwrap agreement, typically litigation, arbitration, or other appropriate ADR or ODR methods. ${ }^{243}$

The online merchant should consider the expenses associated with bringing a claim under the required or offered dispute resolution methods in comparison to the typical dollar amounts in dispute. ${ }^{244}$ The available dispute resolution methods should permit online consumers to resolve the actions in their resident state or to handle them in more cost-effective, non-appearancebased processes, such as telephone, e-mail, or web conferencing. ${ }^{245}$ All costs of the process, what portion of the cost each party will bear, and the terms of payment should be spelled out in the terms of use and should not be so high as to foreclose meaningful opportunities to resolve the dispute. ${ }^{246}$ In addition, collective action in litigation or arbitration should be permitted in order to more efficiently handle numerous small-dollar disputes..$^{247}$

To provide further transparency, the online merchant should publish periodic statistical reports on dispute outcomes. ${ }^{248}$ These public reports will aid consumers in evaluating the likely value of litigation against potential ADR or ODR proceedings. ${ }^{249}$ If arbitration is mandated, participants should be encouraged to allow the publication of decisions, with any confidential or proprietary information redacted from public review. ${ }^{250}$ With this approach, both consumers and merchants will have access to earlier decisions that will help balance the information gap between them derived from previously

\footnotetext{
240 See supra note 218 and accompanying text.

241 See supra notes 214-23 and accompanying text.

242 See supra notes $133-41$ and accompanying text.

243 See supra notes 211-23 and accompanying text.

244 See supra notes $146-48,158-65$ and accompanying text.

245 See supra notes 216,221 and accompanying text.

246 See supra notes $154-57,177-81$ and accompanying text.

247 See supra notes 175-208 and accompanying text.

248 Ponte, supra note 19 , at 477 . See supra notes $166-70$ and accompanying text.

249 Ponte, supra note 19 , at 477.

250 Id.
} 
successful claims and strategies under the mandated ADR or ODR process. $^{251}$

\section{SIMPLIFYING ONLINE Disclosures AND AdOPTING A RATING SYSTEM FOR CLICKWRAP DISPUTE RESOLUTION CLAUSES}

Currently, most websites already provide conspicuous, advance notice of their terms of use and very lengthy clauses on every aspect of the consumer relationship, ${ }^{252}$ including dispute resolution provisions. ${ }^{253}$ In the wake of unconscionability challenges, businesses are predictably moving toward more detailed disclosures as suggested earlier by Professor Leff. Online businesses are no different and typically provide a host of warnings to users before they click their agreement to exhaustive terms of service. But more comprehensive disclosures may not mean any more fairness or understanding, ${ }^{254}$ and may actually be contrary to the typical browsing habits of online users. 255

For example, in Brazil v. Dell, Inc., the court struck down an arbitration clause excluding consolidated actions as unconscionable. ${ }^{256}$ On Dell's website, a hyperlink allows users to review the terms of purchase in advance with the cautionary language:

\section{READ THIS DOCUMENT CAREFULLY! IT CONTAINS VERY IMPORTANT INFORMATION ABOUT YOUR RIGHTS AND OBLIGATIONS, AS WELL AS LIMITATIONS AND EXCLUSIONS THAT MAY APPLY TO YOU. THIS DOCUMENT CONTAINS A DISPUTE RESOLUTION CLAUSE. ${ }^{257}$}

Also, in order to complete an online purchase, online buyers must click on whether or not they agree or disagree, which prompts buyers with the following warning:

251 Id. See supra notes $166-70$ and accompanying text.

252 Friedman, supra note 2, at 398; Tasker \& Pakcyk, supra note 4, at 143, 149.

253 See supra notes 96,115 and accompanying text.

254 Becher, supra note 4, at 742-45. See Leff, supra note 30, at 355.

255 Hillman, supra note 4, at 840-41; Tasker \& Pakcyk, supra note 4, at 105-06. See supra note 33 and accompanying text.

256 Brazil v. Dell Inc., No. C-07-01700 RMW, 2007 WL 2255296, at *8 (N.D. Cal. Aug. 3, 2007).

${ }^{257} I d$. at $* 2$. 
The Terms and Conditions of Sale contain very important information about your rights and obligations as well as limitations and exclusions that may apply to you. They contain limitations of liability and warranty information. They also contain an agreement to resolve disputes through arbitration rather than through litigation. Please read them carefully. ${ }^{258}$

Despite ominous warnings found on websites, few users ever read clickwrap agreements ${ }^{259}$ even though online consumers may have more information at their disposal, ${ }^{260}$ such as explanatory FAQs, and less time pressure to review contracts of adhesion at leisure at home than those standing at the counter of a brick-and-mortar business. ${ }^{261}$ While online users have the opportunity to print, read, and review clickwrap agreements, ${ }^{262}$

$258 I d$. at *1.

259 Friedman, supra note 2, at 378. See Leff, supra note 30, at 351; supra note 4 and accompanying text. Professor Stephen E. Friedman accurately states that:

Consumers making purchases on the Internet are well practiced at scrolling through and "agreeing" to "Terms and Conditions" with extraordinary speed and extraordinarily little thought. These terms frequently include an arbitration provision that deprives the consumer of the right to sue if a dispute arises. The combination of a significant contract provision with a particularly problematic method of contract formation raises serious problems for consumers and for contract law. These problems are exacerbated by the increasing likelihood that the consumer will be viewing and agreeing to on-line contract terms not through the large screen of a desktop computer, but rather through the tiny screen of a cell phone or similar device.

Friedman, supra note 2, at 378; Hillman, supra note 4, at 843-44, 852.

260 Professor Becher recognized the difficulty of imperfect information in consumer contract situations and the tendency of consumers not to read standard form agreements. Becher, supra note 4, at 733-34. He opined that:

[f] ighting the tendency of consumers not to read contracts and coping with asymmetric information have a lot in common. Most people do not bother reading SFCs; therefore, inefficient terms, which benefit the drafters, are more likely to be incorporated. Similarly, efficient clauses that benefit the adherent party are less likely to be included where SFCs are not being read. If adherent parties were more inclined to read the contracts, these inefficiencies would be much less common and acute. In this sense, imposing a duty to read on consumers may arguably reduce asymmetric information, as long as consumers can understand the SFCs they read.

Id.

${ }^{261}$ Hillman, supra note 4, at 840, 852; Kunz et al., supra note 10, at 290.

262 Hillman, supra note 4, at 840; Kunz et al., supra note 10, at 290; Tasker \& Pakcyk, supra note 4, at 114. See supra note 6 and accompanying text. 
online agreements are often excessively lengthy ${ }^{263}$ and squeezed into small pop-up windows that are difficult to read. ${ }^{264}$ Website design principles also focus on the consumer's scanning of web pages, rather than reading each word of text, ${ }^{265}$ and aim to entertain and divert the user's attention away from the mundane terms of use. 266 Furthermore, the casualness of communications on laptops and other hand-held devices detracts from the seriousness of contract formation that the signing of tangible paper documents may reinforce in consumers' minds in the real world. ${ }^{267}$ In addition, law and economics scholars suggest that online consumers are acting efficiently by not reading these online contracts, despite the common law duty to read, since they seldom understand the legalese in online contracts and have no opportunity to negotiate the terms. ${ }^{268}$

Therefore, assembling minimum standards of quality for clickwrap dispute resolution clauses will be useless if they are simply buried in a maze of legalistic clauses. In the online world, disclosure needs to be simplified to reflect common user browsing habits and web design approaches which create content and shape the user experience. ${ }^{269}$ Since web design promotes users scanning information and quickly grasping key components of website content, ${ }^{270}$ online disclosures need to reflect this reality. In an effort to forward Professor Leff's interest in building a "better cabinet,"271 two basic methods might prove useful: (1) the presentation of simple tables at the start

263 Friedman, supra note 2, at 398.

264 Id; ; Tasker \& Pakcyk, supra note 4, at 100, 108-09.

265 Tasker \& Pakcyk, supra note 4, at 105-06. The authors contend that courts often fail to recognize important distinctions between online clickwrap agreements and standard paper contracts based on the "technical nuances" in web design. Id. at 105-06, 109-10. See supra note 33 and accompanying text.

266 See supra notes 33, 264 and accompanying text.

267 Friedman, supra note 2, at 398-99; Hillman, supra note 4, at 841 .

268 Becher, supra note 4, at 729-31, 733-34; Hillman, supra note 4, at 839-41; O'Hara, supra note 4, at 1920-21; Ben-Shahar, supra note 4, at 5. See Senderowicz, supra note 19, at 277-79 (suggesting that form agreements containing arbitration clauses should clearly identify the procedural differences between litigation and arbitration, as well as negotiate financial incentives with consumers who agree to elect arbitration); supra note 140 and accompanying text.

269 See supra note 33 and accompanying text.

270 See supra note 33 and accompanying text.

271 See Leff, supra note 36, at 157. See supra note 37 and accompanying text. 
of an online agreement or site FAQs, ${ }^{272}$ and (2) the creation of a trustmark ratings system for dispute resolution clauses in online consumer transactions. ${ }^{273}$

The first approach is to simplify the presentation of the key characteristics of the clickwrap dispute resolution clauses using a simple table using plain English text. ${ }^{274}$ The table would appear in the agreement dialog box at the start of the online agreement ${ }^{275}$ or in the site's FAQs section. ${ }^{276}$ The table would briefly outline the basics of dispute resolution clauses to aid consumer understanding and comparison of the dispute resolution options with those found on other sites. A consumer trustmark organization, such as the Better Business Bureau Online (BBBOnline) ${ }^{277}$ or Consumer Reports, ${ }^{278}$ might prepare a list of standard questions that would appear in the dispute resolution tables to help establish online conventions that would make the dispute resolution comparison process easier for consumers. ${ }^{279}$ A potential example is illustrated in Exhibit 1 below.

272 See Ben-Shahar, supra note 4, at 32 (suggesting that any boilerplate labeling needs to be in "easily readable formats," similar to food and nutritional labels, and should uniformly summarize key contract terms); infra notes 276-84 and accompanying text.

273 See infra notes 279-84, 293-94 and accompanying text.

274 See Ben-Shahar, supra note 4, at 26; supra notes 64-65 and accompanying text.

275 See, e.g., Doctor's Assocs., Inc. v. Casarotto, 517 U.S. 681 (1996) (holding that the FAA supersedes "Montana's first-page notice requirement," which requires that an ADR clause be underlined, capitalized, and located on first page of contract).

276 See Ponte, supra note 19 , at 455.

277 See Better Business Bureau, Welcome to BBBOnLine, http://www.bbb.org/online (last visited Feb. 1, 2010) (official website of Better Business Bureau).

278 See ConsumerReports.org, Consumer Reports: Expert Product Reviews and Product Ratings from Our Test Labs, http://www.consumerreports.org (last visited Feb. 1,2010 ) (official website of Consumer Reports).

279 See Ben-Shahar, supra note 4, at 32-33. Professor Richard Craswell indicated that disclosure rules should focus on important aspects of an agreement, but not "on every conceivable topic." Richard Craswell, Taking Information Seriously: Misrepresentation and Nondisclosure in Contract Law and Elsewhere, 92 VA. L. REV. $555,577(2006)$. He recommended the prioritization of key aspects of contract disclosure and the development of standard formats, similar to nutritional labeling, to aid consumer comparisons of contract terms which cannot be easily accomplished when relying on case-by-case judicial determinations. Id at $577-78,593$. He added that "otherwise adequate warning might be rendered ineffective by inadequate formatting." Id. at 584-85. 
GETTING A BAD RAP?

Exhibit 1-Sample Clickwrap Dispute Resolution Disclosure Table

\begin{tabular}{|c|c|c|c|}
\hline $\begin{array}{l}\text { IF I HAVE A DISPUTE ABOUT MY ONLINE } \\
\text { PURCHASE, AM I ABLE TO... }\end{array}$ & $Y E S$ & NO & $\begin{array}{l}\text { WHERE } \\
\text { IS IT? }\end{array}$ \\
\hline get help from customer service? & $\sqrt{ }$ & & $\$ 2.0$ \\
\hline go to court in my resident state? & & $\sqrt{ }$ & $\$ 7.0$ \\
\hline $\begin{array}{l}\text { choose method for resolving my claim outside of } \\
\text { courts? }\end{array}$ & & $\sqrt{ }$ & $\S 8.1$ \\
\hline $\begin{array}{l}\text { attend dispute resolution sessions in my resident } \\
\text { state? }\end{array}$ & $\sqrt{ }$ & & $\$ 8.2$ \\
\hline $\begin{array}{l}\text { help pick a qualified neutral third party } \\
\text { decisionmaker? }\end{array}$ & $\sqrt{ }$ & & $\S 8.3$ \\
\hline review the rules of dispute resolution process? & $\sqrt{ }$ & & $\$ 9.0$ \\
\hline resolve my dispute using telephone conferencing? & $\sqrt{ }$ & & $\$ 9.1$ \\
\hline resolve my dispute using e-mail submissions? & $\sqrt{ }$ & & $\$ 9.2$ \\
\hline $\begin{array}{l}\text { resolve my dispute using online or web } \\
\text { conferencing? }\end{array}$ & & $\sqrt{ }$ & $\S 9.3$ \\
\hline $\begin{array}{l}\text { participate in a class action with other consumers } \\
\text { with similar } \\
\quad \text { disputes or consumer groups? }\end{array}$ & & $\sqrt{ }$ & $\$ 9.4$ \\
\hline seek punitive and other non-economic damages? & & $\sqrt{ }$ & $\$ 10$ \\
\hline $\begin{array}{l}\text { find average costs for resolving my claim outside } \\
\text { of courts? }\end{array}$ & $\sqrt{ }$ & & $\begin{array}{c}F A Q- \\
\# 11\end{array}$ \\
\hline $\begin{array}{l}\text { review past reports on outcomes of earlier } \\
\text { disputes? }\end{array}$ & $\sqrt{ }$ & & $\begin{array}{c}F A Q- \\
\# 12 \\
\end{array}$ \\
\hline
\end{tabular}

However, some consumers may have difficulty effectively assessing and comparing the dispute resolution information contained in the proposed table. ${ }^{280}$ The consumers may not have enough understanding of dispute resolution processes or may find it hard to weigh the values of different dispute resolution options ${ }^{281}$ loaded with contingencies they may never use. 282

280 Ben-Shahar, supra note 4, at 18-19, 26-27. See supra notes 140,270 and accompanying text.

281 The general public still lacks sufficient information about, and experience with, ADR and ODR to make informed judgments about appropriate methods of dispute resolution. See Cathy A. Costantino \& Christina Sickles Merchant, Designing Conflict Management Systems-A Guide To Creating Productive and Healthy Organizations, in ALTERNATIVE DisPUTE RESOlUTION: STRATEGIES FOR LAW AND BUSINESS 1259, 1264 , 
Professor Leff contended that legislative action and administrative enforcement against abusive consumer practices were the better approach to dealing with unconscionability in mass-produced consumer contracts of adhesion. ${ }^{283}$ Yet, efforts to spell out special requirements for clickwrap dispute resolution clauses would run afoul of the FAA's requirement that arbitration clauses be treated the same as other contracts ${ }^{284}$ and E-SIGN's call for equality between offline and online contracts. ${ }^{285}$

Therefore, it would be useful to have a market-based approach to the issue of adequate compliance with minimum quality standards. ${ }^{286}$ Rating systems utilizing alphabetical or percentage grades or star systems are common on the internet, including the use of online evaluations of law firms. ${ }^{287}$ Online consumers are used to scanning and relying upon these

1266 (E. Wendy Trachte Huber \& Stephen K. Huber eds., 1996) (outlining that one major principle of ADR is to "[m]ake sure that disputants have the necessary knowledge and skill to choose and use ADR"); Robert C. Bordone, Electronic Online Dispute Resolution: A Systems Approach-Potential, Problems, and a Proposal, 3 HARV. NEGOT. L. REV. 175, 196 (1998) (recognizing that there are major challenges in offering simple dispute resolution processes to deal with conflicts); Lucille M. Ponte, Throwing Bad Money After Bad: Can Online Dispute Resolution (ODR) Really Deliver the Goods for the Unhappy Internet Shopper?, 3 TUL. J. TECH. \& INTELL. ProP. 55, 90-91 (2001) (noting that the "lack of public awareness and education about ADR principles and methods" is a major obstacle in public confidence in and use of ADR and ODR); BenShahar, supra note 4 , at 21.

282 See Leff, supra note 36 , at 148; Leff, supra note 30 , at 351 ; Ben-Shahar, supra note 4 , at 18 . In the unconscionability context, Professor Leff recognized that consumers often lack the ability to adequately assess boilerplate contingencies in form contracts. Leff, supra note 36 , at 148 . See Hillman, supra note 4, at 841, 850. Furthermore, Professor Hillman also warned that the average consumer tends "to equate 'low probability' risks with 'zero probability' risks." Id. at 841 . See supra notes $20,140,228$, 262 and accompanying text.

${ }^{283}$ Leff, supra note 30 , at $356-58$. See supra notes $135,216,221$ and accompanying text.

284 See supra note 8 and accompanying text.

285 See supra note 9 and accompanying text.

286 See infra notes 289-94 and accompanying text.

287 See Stephanie Francis Ward, Grade Anxiety: Firms Fret About Clients Rating Their Work, 96 A.B.A.J. 48 (2010), available at http://www.abajournal.com /magazine/article/grade_anxiety (addressing the legal community's concerns about client review and peer-endorsement rating sites for law firms). But see Ben-Shahar, supra note 4 , at 31-33 (suggesting the possible use of a rating system but wondering whether the lack of rating systems for e-commerce contracts may indicate a lack of consumer demand for such ratings in lower cost online business transactions as compared to real world transactions involving lending, mortgages, car purchases, and residential leases). 


\section{GETTING A BAD RAP?}

online rating conventions in making determinations about their online purchasing practices. ${ }^{288}$ Some rating systems are based on consumer ratings while others may be a mix of peer endorsement and customer reviews, ${ }^{289}$ with unsophisticated consumers looking to more savvy consumers to point out flaws in form agreements, such as onerous dispute resolution clauses. 290

288 A recent JupiterResearch study found that $77 \%$ of online consumers will review user ratings and reviews, and $66 \%$ will consider online consumer purchasing recommendations before making online purchases. Study Finds Consumers Rely on Ratings, Reviews and Recommendations During Recession, Feb. 26, 2009, $\mathrm{http}: / / \mathrm{www}$.emarketingandcommerce.com/article/study-finds-consumers-rely-ratingsreviews-and-recommendations-during-recession (last visited Nov. 24, 2010). Other studies show that a majority of online consumers will rely on user ratings to make purchasing decisions and will pay higher prices for products that garnered better consumer ratings. Press Release, PRWeb, Consumers Turn to Online Ratings and Reviews, as Sites Respond to Concerns (Feb. 28, 2008), available at http://www.prweb.com/releases/2008-02-28/ratings/prweb729043.htm. See Ben-Shahar, supra note 4 , at 28-30.

289 Ben-Shahar, supra note 4, at 28-30. See, e.g., ConsumerSearch.com, Product Reviews and Reports, http://www.consumersearch.com (last visited Feb. 1, 2010) (aggregating and analyzing product reviews and making product recommendations); Edmunds.com, New Cars, Used Cars, Car Reviews and Pricing, http://www.edmunds.com (last visited Feb. 1, 2010) (acting as a website that provides both expert and consumer ratings on new and used vehicles); Epinions.com, Reviews from Epinions, http://www.epinions.com (last visited Feb. 1, 2010) (acting as a website that collects opinions and reviews of consumers on best products and services, and provides price comparisons and ratings of online shopping websites). See Ben-Shahar, supra note 4 , at 30 . Professor Ben-Shahar suggests that perhaps free downloadable software could be developed to help analyze boilerplate provisions (hypothetically "EULAlyzer"). Id. However, he recognizes the difficulty in creating a methodology for assessing the value of a variety of e-commerce clauses for individual consumers. Id. at 29.

\section{See Baird, supra note 125, at 133. Professor Douglas G. Baird notes that:}

[b]uyers often have little choice over the way that a particular seller bundles her product. The inability to choose is a by-product of mass production. Furthermore, the typical buyer cannot rely on her own expertise or her ability to dicker with her seller. But when the market works effectively, she can rely on the presence of other, more sophisticated buyers. As long as there are enough sophisticated buyers aware of the importance of having the right product attributes and the right legal terms, the seller must provide those. Thus, at first approximation, boilerplate is something the typical consumer can safely ignore most of the time. Even if the boilerplate is buried in fine print and written in ancient Greek, as long as the consumer can observe that knowledgeable buyers are satisfied with products that contain this boilerplate, she can be too. 
However, in the specialized realm of dispute resolution clauses, a consumer trustmark organization would be better suited to objectively evaluate and rate dispute resolution clauses contained in online merchants' terms of use for compliance with the proposed minimum quality standards. ${ }^{291}$ Similar to what is already done with other product or service ratings online, the organization would provide a rating of, or grade on, a particular online merchant's compliance with the minimum quality standards for dispute resolution clauses present in the merchant's terms of use. The score or rating would appear on the online merchant's homepage or at the start of the dialog box containing the clickwrap agreement. In addition, the trustmark organization could provide updates on merchant ratings through a blog or in downloadable reports for consumer review and use in their online activities. Consumers would be allowed to post their own experiences resolving a dispute with an online merchant in a database searchable by the online merchant's name. E-businesses with high scores or ratings would trumpet their user-friendly dispute resolution provisions to consumers to try to gain an advantage in the marketplace. Those online merchants with low scores or ratings might become more motivated to improve the quality of their clickwrap dispute resolution clauses in order to more effectively compete against other higher-rated online merchants. ${ }^{292}$

\section{CONCLUSION}

Id. However, Professor Hillman warns that some markets which lack sufficient competition will allow businesses to lay down harsh terms, assuming that they will lose only a "small cadre of readers and dictate onerous terms to the nonreaders." Hillman, supra note 4 , at 843 .

291 Currently, the Better Business Bureau has established the BBBOnLine Reliability Program which provides a trustmark for online businesses that comply with its code of responsible online commercial conduct. Better Business Bureau, Reliability Program Requirements, http://www.bbbonline.org/reliability/requirement_small.asp (last visited Feb. 5, 2010). Under the BBBOnLine trustmark program, the e-business must agree to participate in the BBB's conflict resolution programs which involve informal hearings before volunteer hearing officers or binding arbitration under the BBB Rules of Arbitration. BBBOnLine, Dispute Resolution, http://www.bbbonline.org/reliability/dr.asp (last visited Feb. 5, 2010). E-businesses may select their own ADR/ODR provider as long as that process meets certain BBB criteria on party assent, transparency, fairness, and impartiality. Id. See Ponte, supra note 19, at 461-64.

292 Hiliman, supra note 4 , at $845-46$. See supra notes $272-73$ and accompanying text. 
Case-by-case battles over online dispute resolution clauses have yielded inconsistent results and slow progress toward improving fundamental fairness for consumers. Efforts to expand disclosures in terms of use provide mainly legal notice to consumers who seldom read them or cannot sufficiently understand the legalese in order to assess their dispute resolution options. These adhesive clauses should be viewed not as contracts, but products that should meet certain minimum quality standards. These basic standards should address mutuality, choice, cost-effectiveness, and transparency in offering dispute resolution options in clickwrap agreements. It is beneficial to present a simple chart that explains the essential characteristics of the dispute resolution clause and provides essential information in plain English for consumer comparisons. In addition, a simple rating system by a trustmark organization should be established to rank or grade clauses, providing a quick snapshot of information in line with typical online browsing behavior. Together, these proposals will help to elevate the overall quality of dispute resolution clauses contained in terms of use as online merchants compete for better ratings. Without these fundamental and straightforward changes, online dispute resolution clauses in clickwrap agreements will be unlikely to shake their bad rap in the online world. 
